\title{
Drought Coincided with, but Does Not Explain, Late Holocene Megafauna Extinctions in SW Madagascar
}

\author{
Sean W. Hixon ${ }^{1, * \mathbb{D}}$, Jason H. Curtis ${ }^{2} \mathbb{D}$, Mark Brenner ${ }^{2}$, Kristina G. Douglass ${ }^{3}$, Alejandra I. Domic ${ }^{4}$, \\ Brendan J. Culleton ${ }^{5}$, Sarah J. Ivory ${ }^{6}\left(\mathbb{D}\right.$ and Douglas J. Kennett ${ }^{1}$
}

1 Department of Anthropology, University of California, Santa Barbara, CA 93106, USA; kennett@anth.ucsb.edu

2 Department of Geological Sciences \& Land Use and Environmental Change Institute, University of Florida, Gainesville, FL 32611, USA; curtisj@ufl.edu (J.H.C.); brenner@ufl.edu (M.B.)

3 Department of Anthropology \& Institutes of Energy and the Environment, Pennsylvania State University, University Park, PA 16802, USA; kdouglass@psu.edu

4 Department of Anthropology, Department of Geosciences, and Earth and Environmental Systems Institute, Pennsylvania State University, University Park, PA 16802, USA; aid4@psu.edu

5 Institutes of Energy and the Environment, Pennsylvania State University, University Park, PA 16802, USA; bjc23@psu.edu

6 Department of Geosciences \& Earth and Environmental Systems Institute, Pennsylvania State University, University Park, PA 16802, USA; sji15@psu.edu

* Correspondence: hixon@ucsb.edu

check for

updates

Citation: Hixon, S.W.; Curtis, J.H.; Brenner, M.; Douglass, K.G.; Domic,

A.I.; Culleton, B.J.; Ivory, S.J.; Kennett,

D.J. Drought Coincided with, but

Does Not Explain, Late Holocene

Megafauna Extinctions in SW

Madagascar. Climate 2021, 9, 138.

https://doi.org/10.3390/cli9090138

Academic Editors: Terri Schulz and Timothy G. F. Kittel

Received: 1 July 2021

Accepted: 26 August 2021

Published: 1 September 2021

Publisher's Note: MDPI stays neutral with regard to jurisdictional claims in published maps and institutional affiliations.

Copyright: (c) 2021 by the authors Licensee MDPI, Basel, Switzerland. This article is an open access article distributed under the terms and conditions of the Creative Commons Attribution (CC BY) license (https:// creativecommons.org/licenses/by/ $4.0 /)$.

\begin{abstract}
Climate drying could have transformed ecosystems in southern Madagascar during recent millennia by contributing to the extinction of endemic megafauna. However, the extent of regional aridification during the past 2000 years is poorly known, as are the responses of endemic animals and economically important livestock to drying. We inferred 1600 years of climate change around Lake Ranobe, SW Madagascar, using oxygen isotope analyses of monospecific freshwater ostracods (Bradleystrandesia cf. fuscata) and elemental analyses of lake core sediment. We inferred past changes in habitat and diet of introduced and extinct endemic megaherbivores using bone collagen stable isotope and ${ }^{14} \mathrm{C}$ datasets $(n=63)$. Extinct pygmy hippos and multiple giant lemur species disappeared from the vicinity of Ranobe during a dry interval $~ 1000-700$ cal yr BP, but the simultaneous appearance of introduced cattle, high charcoal concentrations, and other evidence of human activity confound inference of drought-driven extirpations. Unlike the endemic megafauna, relatively low collagen stable nitrogen isotope values among cattle suggest they survived dry intervals by exploiting patches of wet habitat. Although megafaunal extirpations coincided with drought in SW Madagascar, coupled data from bone and lake sediments do not support the hypothesis that extinct megafauna populations collapsed solely because of drought. Given that the reliance of livestock on mesic patches will become more important in the face of projected climate drying, we argue that sustainable conservation of spiny forests in SW Madagascar should support local livelihoods by ensuring that zebu have access to mesic habitat. Additionally, the current interactions between pastoralism and riparian habitats should be studied to help conserve the island's biodiversity.
\end{abstract}

Keywords: stable isotopes; radiocarbon; charcoal; aridification; deforestation; zebu; pygmy hippos; giant lemurs

\section{Introduction}

Water scarcity, exacerbated by colonial legacies of land dispossession [1], has left subsistence farmers and pastoralists in the grip of famine in southern Madagascar [2], and climate change simulations suggest that the region will experience more periods of severe drought during the next century [3]. Paired records of past climate change and biotic responses to such fluctuations can identify vulnerability to drought and inform management plans designed to promote human and ecosystem health [4]. The goal of this study was to use multiple analyses of ancient lake sediments and herbivore bone collagen 
to assess the past response of animals to drought and infer drivers of past megafaunal extinction. Such research on past patterns of habitat use has important implications for modern conservation work that sets restoration targets and identifies the different ways in which humans impact biodiversity [5]. Specifically, because the composition of modern ecosystems is the product of processes that operate on multiple timescales [6], conservation efforts informed by only direct observations of living organisms risk operating under false assumptions regarding the vulnerability of organisms and ecosystems to particular stressors [5,7]. Despite an increasingly well-resolved record of aridification in Late Holocene SW Madagascar [8-11], biotic responses to regional climate change during the $\sim 2000$-year human history on the island are poorly known. We provide historical context for the current drought in SW Madagascar by inferring changes in past water availability using geochemical measures (ostracod $\delta^{18} \mathrm{O}$ and $\delta^{13} \mathrm{C}$, organic matter $\delta^{15} \mathrm{~N}$ and $\delta^{13} \mathrm{C}, \% \mathrm{CaCO}_{3}$, heavy element abundance, magnetic susceptibility, and charcoal influx) from a sediment core collected in Lake Ranobe, and by characterizing the responses of local endemic and introduced animals to past climate changes through analysis of purified bone collagen $\left({ }^{14} \mathrm{C}, \delta^{13} \mathrm{C}\right.$, and $\left.\delta^{15} \mathrm{~N}\right)$.

\subsection{Climate Change in SW Madagascar}

Ancient dunes and the diversity of endemic succulents attest to a long history of water scarcity in SW Madagascar. Although perennial bodies of water exist in some artesian springs and pans [10], most surface fresh water in the area is seasonally ephemeral. The aridity of the region reflects an orographic rain shadow in the west and absence of the influence of the Intertropical Convergence Zone during the austral summer [12]. Oscillations in sea surface temperatures also affect Madagascar's climate through the Indian Ocean Dipole (IOD). Positive IOD states occur when westerly winds weaken and easterly winds sometimes form, which brings cold water to the surface in the eastern Indian Ocean and enables warm water and wet air masses to concentrate in the west, around Madagascar [13].

A paleohydrological record from Lac Ihotry (in the coastal plains $\sim 100 \mathrm{~km}$ north of Ranobe) revealed a drying trend during the Late Holocene ( 3 ka to present) that involved a decline in the water table and salinization of coastal pans and wetlands [10]. That record probably reflects, in part, a drop in relative sea level and coastal water tables [14,15]. However, a speleothem from Rodrigues Island in the western Indian Ocean recorded at least four megadroughts over the past 2000 years that could have also affected southern Madagascar [16], and a speleothem from SW Madagascar recorded a prolonged drought $\sim 1000$ years ago [9].

Lake Ranobe is a shallow ( $<3 \mathrm{~m}$ deep), closed basin, and its geochemistry was sensitive to regional aridification during the Late Holocene. The $\delta^{18} \mathrm{O}$ values of subfossil ostracod shells (Bradleystrandesia cf. fuscata), supported by complementary lines of elemental data, serve as a proxy for the past ratio of evaporation to precipitation $(\mathrm{E} / \mathrm{P})$ around the lake. Whereas both temperature and the $\delta^{18} \mathrm{O}$ value of lake water determine the $\delta^{18} \mathrm{O}$ values in ostracod shell calcite, water temperature likely had little influence on shifts in our ostracod $\delta^{18} \mathrm{O}$ record, because: (1) seasonal differences in temperature of fresh water bodies in the tropics are small, (2) ostracods may survive over multiple seasons, thereby integrating minor intra-annual differences in lake water $\delta^{18} \mathrm{O}$, and (3) measurements of ostracod $\delta^{18} \mathrm{O}$ were run on multiple individuals from a stratigraphic sample, thus integrating changes in lake water $\delta^{18} \mathrm{O}$ over both seasons and years [17]. Lake water $\delta^{18} \mathrm{O}$ values were thus the primary influence on ostracod $\delta^{18} \mathrm{O}$ values, and lake water $\delta^{18} \mathrm{O}$, in turn, is sensitive to integrated rainfall $\delta^{18} \mathrm{O}$ and intensity of evaporation. Although average rainfall $\delta^{18} \mathrm{O}$ values can differ by as much as $8 \%$ between wet and dry months in the central highlands of Madagascar (Antananarivo, IAEA GNIP Database), the arid SW part of the country receives rainfall almost entirely during a single wet season. Because the vapor pressure of $\mathrm{H}_{2}{ }^{16} \mathrm{O}$ is greater than that of $\mathrm{H}_{2}{ }^{18} \mathrm{O}$, evaporation causes preferential loss of $\mathrm{H}_{2}{ }^{16} \mathrm{O}$ from the lake, with consequent ${ }^{18} \mathrm{O}$ enrichment in lake water and associated ostracod carbonates. High 
$\mathrm{E} / \mathrm{P}$ thus results in higher $\delta^{18} \mathrm{O}$ values in ostracod shells, and, in extreme cases, promotes authigenic carbonate precipitation, which leads to higher $\mathrm{CaCO}_{3}$ concentration and $\mathrm{Ca} / \mathrm{Zr}$ ratios in lake sediment $[18,19]$. Low $\mathrm{E} / \mathrm{P}$ leads to lower $\delta^{18} \mathrm{O}$ values in ostracod shells, and higher rainfall may be associated with greater erosion, higher magnetic susceptibility of the sediment, and greater abundance of mobile elements such as $K[18,20,21]$.

\subsection{Animal Responses to Climate Change}

In Madagascar, it remains unclear whether a synergy involving Late Holocene aridification and the spread of pastoralism contributed to the eventual extinction of endemic fauna [22]. Aridification reduces access to surface water and certain types of forage. Consequently, drought-sensitive species move to areas that host a narrow range of suitable habitat and forage, whereas drought-tolerant species exploit whatever habitat is most abundant, regardless of dryness (Figure 1). Different responses of herbivores to aridification can be tracked by considering how aspects of their niche vary across regional conditions. The long-term drought tolerance of recently extinct endemic megafauna, such as pygmy hippos (Hippopotamus spp.) and giant tortoises (Aldabrachelys spp.) and economically important, introduced zebu cattle (Bos taurus indicus), are poorly known. Modern zebu herds browse in a wide range of habitats, yet they migrate seasonally to track fresh water and fodder [23]. Endemic megafauna may have been drought-tolerant given that they persisted through relatively severe Pleistocene climate fluctuations [24,25], but they nevertheless went extinct after the spread of pastoralism and forest clearance after $1000 \mathrm{BP}[22,25]$.
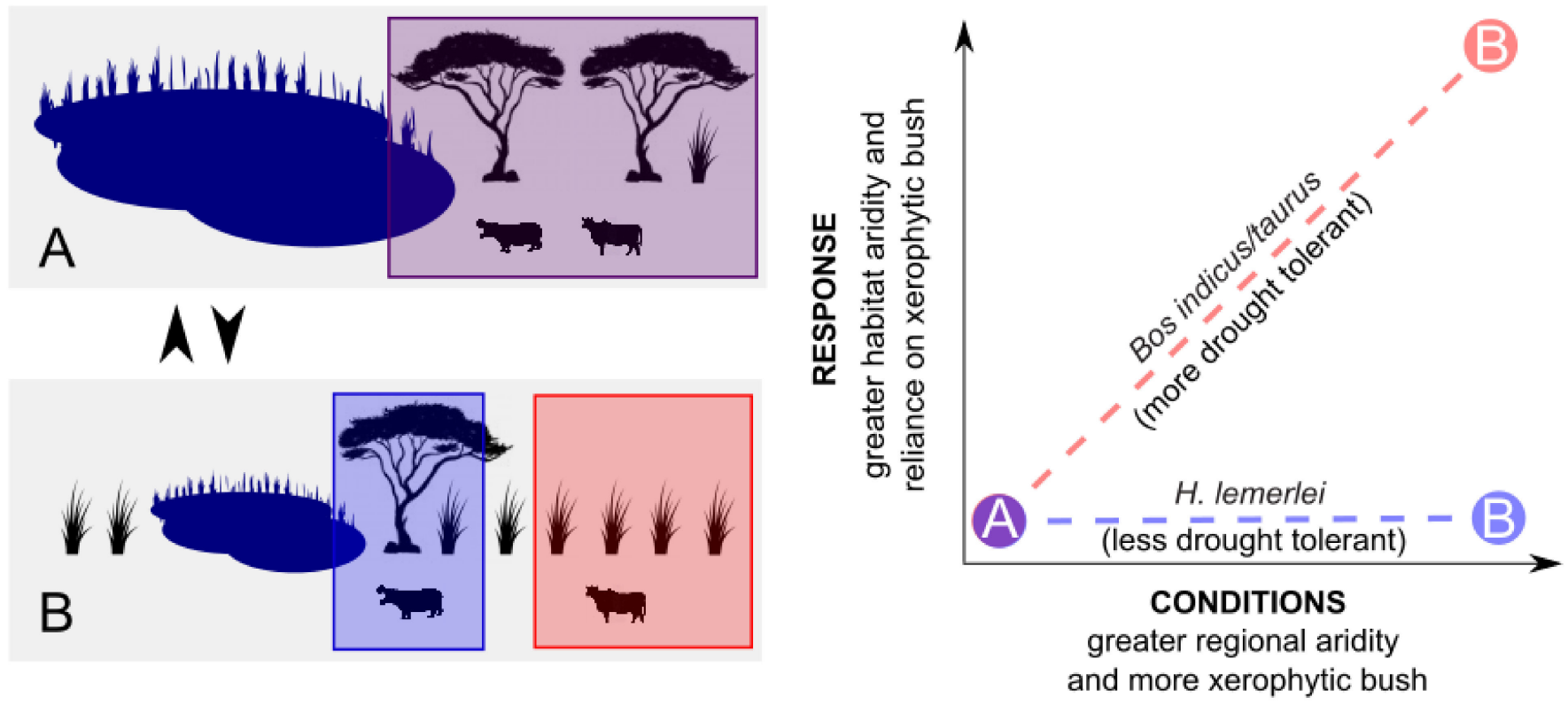

Figure 1. Hypothetical divergent responses of herbivores to drought and associated vegetation change. During mesic conditions (A), zebu (Bos taurus indicus) and pygmy hippos (H. lemerlei) exploit abundant wet habitat and consume relatively few xerophytic plants. During dry conditions (B), zebu exploit relatively abundant arid habit and have a greater reliance on xerophytic bush, while hippos continue to exploit relatively scarce mesic habitat and forage. In this case, the flexibility of zebu makes them relatively drought-tolerant. Note that it is possible that neither zebu nor pygmy hippos are, in fact, drought-tolerant as envisioned in this figure. Paleoclimatological and palynological data can characterize regional conditions and stable isotope data from herbivore bone proteins can characterize the responses of different species to changing climate. This simplified scenario does not consider other potentially important variables that may have affected fauna, such as human-mediated deforestation and the impacts of exotic megaherbivores on vegetation.

We used radiocarbon $\left({ }^{14} \mathrm{C}\right)$ and stable isotope data from herbivore bone collagen to test the hypothesis that zebu are drought-tolerant relative to extinct endemic herbivores. Extirpations that coincided with past droughts can indicate drought sensitivity. Bone ${ }^{14} \mathrm{C}$ datasets provide robust estimates of the timing of extirpation and introduction, and 
they complement estimates of large-herbivore biomass inferred from coprophilous fungus (Sporormiella spp.) spore counts [26]. Stable carbon isotope $\left(\delta^{13} C\right)$ and nitrogen isotope $\left(\delta^{15} \mathrm{~N}\right)$ data from herbivore bones reflect aspects of both diet and habitat and can track longterm changes in aridity to different extents. The photosynthetic pathway used by plants exerts the strongest influence on $\delta^{13} \mathrm{C}$ values in plant tissues and herbivore collagen $[27,28]$. Plants that use the $C_{3}$ photosynthetic pathway (primarily trees, shrubs, and herbs) tend to be depleted in ${ }^{13} \mathrm{C}$ (i.e., have more negative $\delta^{13} \mathrm{C}$ values) relative to plants that use the $\mathrm{C}_{4}$ (primarily tropical grasses) or CAM pathway (primarily succulents, see [22] for data from each of these groups in SW Madagascar). Local environmental conditions influence plant and herbivore $\delta^{15} \mathrm{~N}$ values such that plants and herbivores in relatively arid landscapes have relatively high $\delta^{15} \mathrm{~N}$ values $[29,30]$. For example, in Madagascar's Beza Mahafaly Special Reserve, which lies in the spiny thicket $100 \mathrm{~km} \mathrm{SE}$ of Lake Ranobe (Figure 2), mouse lemurs (Microcebus griseorufus) that live in the lush riparian forest have bulk tissue $\delta^{15} \mathrm{~N}$ values that are $\sim 2 \%$ lower than those that live in the surrounding xerophytic thicket [30].
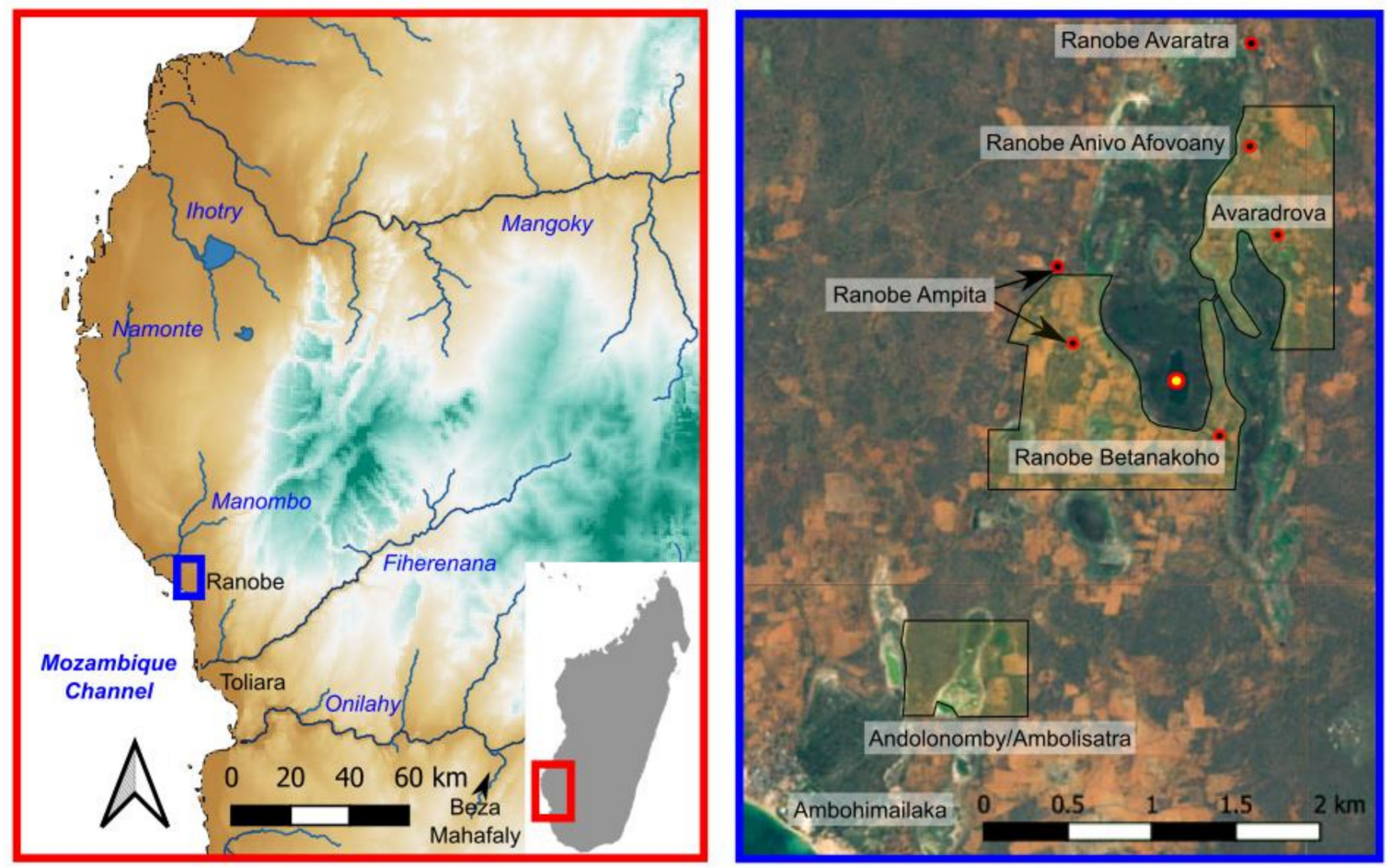

Figure 2. Regional map of southwest Madagascar showing the location of Lake Ranobe relative to other bodies of water, the regional capital (Toliara), and other sites discussed in the text. Note that terrain is highlighted in color, with lowlands (100 m asl) marked in brown and plateaus (up to $1000 \mathrm{~m}$ asl) marked in green The Lake Ranobe inset at right (Sentinel 2 satellite imagery) includes the sediment coring site marked with a red and yellow circle, and the archaeological survey areas marked as lightly shaded yellow areas. Modern towns and hamlets are labelled, and hamlets around Lake Ranobe are marked with red and black circles. The vegetation around Lake Ranobe is currently a mosaic of cultivation (light brown and green) and dry spiny forest thicket (gray brown).

Comparison of regional aridity records from Lake Ranobe with records from local animals sensitive to diet and habitat enabled us to compare taxon-specific responses to past environmental change. We identify drought-tolerant herbivore taxa as those that exploited dry habitat (with relatively high $\delta^{15} \mathrm{~N}$ values) and consumed xerophytes (plants with relatively high $\delta^{13} \mathrm{C}$ values) when the region was relatively dry (Figure 1). Droughtsensitive herbivore taxa are identified as animals that move to stay within their preferred habitat, and maintain relatively constant $\delta^{15} \mathrm{~N}$ and $\delta^{13} \mathrm{C}$ values, even during times of regional aridification. 


\subsection{Regional Setting}

The coastal plains of Quaternary alluvium that extend north of Toliara, SW Madagascar, are broken by an Eocene limestone escarpment to the east and include small lakes such as Ranobe (meaning "big water" in Malagasy) and some relatively larger pans such as Lac Ihotry (Figure 2). Lake Ranobe (S 23.03120 $, \mathrm{E} 43.60483^{\circ}, \sim 20$ masl) is bounded by dunes between the Manombo and Fiherenana drainages, which today host a suite of cultivated crops (e.g., sugarcane, sweet potato, cassava, and beans) and fragments of endemic spiny forest that include members of the families Didiereaceae and Euphorbiaceae. The lake possesses rooted emergent (e.g., Cyperaceae, Typhaceae) and floating-leaved plants (Nymphaceae) and receives groundwater inputs that flow through sediments dominated by quartz sand, which extend over a catchment of $\sim 150 \mathrm{~km}^{2}$ (calculated from SRTM DEM; NGA and NASA, global). During September 2017, Lake Ranobe was smaller $\left(\sim 0.5 \mathrm{~km}^{2}\right)$, but somewhat deeper (maximum depth, $z_{\max }=2.47 \mathrm{~m}$ ), than nearby coastal pans in the region such as Thotry and Namonte $\left(z_{\max }=1-2 \mathrm{~m}\right)$, and local informants considered these differences in depth typical. The monsoonal climate around Toliara is characterized by monthly average air temperatures that range between $25^{\circ} \mathrm{C}$ and $30^{\circ} \mathrm{C}$, and annual precipitation ( $400 \mathrm{~mm}$ ) that falls primarily during austral summer, November-March [31]. Lake Ranobe lies $\sim 3.5 \mathrm{~km}$ inland from the coastal village of Ambohimailaka, which itself is near a series of shallow ponds (Andolonomby/Ambolisatra) that have been mined for megafauna bones since the $19^{\text {th }}$ century [8,32-34]. The archaeology around Lake Ranobe is poorly described, yet pygmy hippo bones from Andolonomby/Ambolisatra show evidence of human modification [35], and road construction uncovered recent $(<200 \mathrm{BP})$ pottery fragments [36].

\section{Materials and Methods}

\subsection{Sediment Collection and Archaeological Survey}

We retrieved duplicate sediment cores with lengths of $237 \mathrm{~cm}$ and $243 \mathrm{~cm}$ from Lake Ranobe (Figure 2) in September 2017. A sediment-water interface core (upper $65 \mathrm{~cm}$ ) was collected using a piston corer that employs a 2.75 "-inner diameter (ID) polycarbonate core barrel [37]. These uppermost, poorly consolidated sediments were maintained in a vertical position, extruded, and sampled in the field at 2-cm intervals. Deeper, more consolidated sediments were collected in up to 1-m-long sections using a Colinvaux-Vohnout-type corer, modified to employ clear polycarbonate core barrels (2.125" ID). The deeper core sections were shipped intact to the US and opened at the University of Florida (UF), where they were split lengthwise, photographed, and sampled at $1-\mathrm{cm}$ resolution for geochemical and charcoal analyses.

Bones used in this study came from both existing collections and our surface archaeological survey in the vicinity of Lake Ranobe. We worked with the Morombe Archaeological Project during September 2019 to survey $\sim 2.4 \mathrm{~km}^{2}$ of land in the vicinity of Lake Ranobe (Figure 1). A crew of 10, each spaced $\sim 10 \mathrm{~m}$ apart, walked E-W transects and collected all surface bones, ceramics, shells, iron, and imported glass and stone (Dataset S1). Survey samples were stored at the University of Toliara's Centre de Documentation et de Recherche sur l'Art et les Traditions Orales à Madagascar (CeDRATOM), and bone samples were shipped to Pennsylvania State University (PSU) for ${ }^{14} \mathrm{C}$ analysis by accelerator mass spectrometer (AMS).

\subsection{Chronology}

We ${ }^{14} \mathrm{C}$-dated 15 samples from the Lake Ranobe sediment core, which included macrobotanical remains such as charcoal and seeds $(n=12)$, bulk sediment organic matter $(n=1)$, terrestrial bird eggshell carbonate $(n=1)$, and ostracod carbonate $(n=1$, Dataset S3). All samples were pretreated and graphitized in the PSU Stable Isotope Geochemistry Laboratory and analyzed on the PSU AMS. We removed contaminating humates and carbonates from macrobotanical remains and bulk sediment organic matter prior to analysis by pre-treating samples with acid/base/acid (ABA) washes that involved $20 \mathrm{~min}$ at $60^{\circ} \mathrm{C}$ 
with $1 \mathrm{~N} \mathrm{HCl}$ and $1 \mathrm{~N} \mathrm{NaOH}$ (for charred remains) or $0.1 \mathrm{~N} \mathrm{NaOH}$ (for uncharred remains). We pre-treated carbonate samples with a $10 \%$ etch in $0.01 \% \mathrm{HCl}$ solution for $20 \mathrm{~min}$ at $60{ }^{\circ} \mathrm{C}$. We calibrated all dates in OxCal 4.4 (University of Oxford, UK) using SHCal20 [38] and developed an age-depth model using the $\mathrm{R}$ package (Bacon v2.4.3, see model settings in Dataset S4) [39].

Four ${ }^{14} \mathrm{C}$ dates from aquatic plant remains or bulk sediment are subject to reservoir effects and were thus excluded from the final age-depth model (based on the remaining 11 dates). Specifically, bioturbation, different depositional pathways, or ${ }^{14} \mathrm{C}$ reservoir effects in lake water may account for the date reversals in the sequence, but it is not possible to determine with certainty which process was responsible. Shells of burrowing planorbid snails (cf. Segmentorbis angustus) exist throughout the sequence. However, intact laminae, stratigraphic correlation between adjacent core sections, and comparable ages of charcoal from initial (PSUAMS-3523, $600 \pm 20 \mathrm{BP}, 126 \mathrm{~cm}$ depth) and adjacent core sections (PSUAMS-6328, $460 \pm 20 \mathrm{BP}, 126.5 \mathrm{~cm}$ depth), suggest consistent stratigraphy and relatively little or no bioturbation. It is possible that charcoal and terrestrial seeds require more time than aquatic plant remains and ostracods to enter the sediment record, yet anomalously old outliers in the sequence were confidently identified as aquatic plant seeds (Najas sp. from $115.5 \mathrm{~cm}$ depth, PSUAMS-5153, $1560 \pm 15$ BP and Najas sp. and Potamogetonaceae from $180.5 \mathrm{~cm}$ depth, PSUAMS-5155 $1875 \pm 25 \mathrm{BP}) . \mathrm{A}{ }^{14} \mathrm{C}$-depleted reservoir of dissolved inorganic carbon (DIC) in lake water may yield ${ }^{14} \mathrm{C}$ dates for aquatic plant remains and ostracods that are hundreds to thousands of years older than their true age [40]. However, comparable ages for ostracod (PSUAMS-6334, $650 \pm 20 \mathrm{BP}$ ) and charcoal fragments (PSUAMS-6328, $460 \pm 20 \mathrm{BP}$ ) from $126.5 \mathrm{~cm}$ depth suggest that the DIC in Lake Ranobe, at least at that time, was not substantially ${ }^{14} \mathrm{C}$-depleted. Because no single mechanism explains all the outliers in our core chronology, we chose to exclude the aquatic plant and mixed organic ${ }^{14} \mathrm{C}$ data (the two youngest and two oldest outliers) to develop the age-depth model.

We obtained ${ }^{14} \mathrm{C}, \delta^{13} \mathrm{C}$, and $\delta^{15} \mathrm{~N}$ data from remains of zebu (Bos taurus indicus, $n=8$ ) and stable isotope data from modern bones of four introduced individuals collected on the margins of Lake Ranobe: zebu $(n=1)$, goats (Capra hircus, $n=2)$, and bush pig (Potamochoerus larvatus, $n=1$ ). Prior to collagen extraction and stable isotope analysis, we extracted lipids from the four modern bone samples using $3 \times$ sonication in 2:1 DCM:MeOH, followed by rinses in DI water (modified from [41]). Collagen extraction for both modern and ancient samples involved demineralization in $0.5 \mathrm{~N} \mathrm{HCl}$ followed by gelatinization in $0.01 \mathrm{~N} \mathrm{HCl}$ at $60^{\circ} \mathrm{C}$ for $10 \mathrm{~h}$. We purified crude collagen extracts from ancient samples through ultrafiltration [42-44] or XAD resin column chromatography [45-47]. Sample pretreatment took place at the PSU Human Paleoecology and Isotope Geochemistry Lab. We determined $\delta^{13} \mathrm{C}, \delta^{15} \mathrm{~N}$, and $\mathrm{C}: \mathrm{N}$ values on collagen from all 12 individuals at the Yale Analytical and Stable Isotope Center and the University of New Mexico's Center for Stable Isotopes, where the mean precision of $\delta^{13} \mathrm{C}$ and $\delta^{15} \mathrm{~N}$ standard measurements across runs was $\leq 0.1 \%$. The four modern samples and all eight of the ancient samples that we ${ }^{14} \mathrm{C}$-dated at the PSU AMS facility had good preservation and displayed absence of contaminants as evaluated by $\mathrm{C}: \mathrm{N}, \delta^{13} \mathrm{C}$, and $\delta^{15} \mathrm{~N}$ values $[44,48-50]$. We calibrated all bone dates in OxCal 4.4 using SHCal20 [38], and we corrected $\delta^{13} \mathrm{C}$ values from modern bones for the Suess Effect so that they are comparable with data from subfossil specimens, following the approach of Crowley and Godfrey ([51], Dataset S2).

We supplemented this dataset with previously published bone data from animals recovered within $\sim 30 \mathrm{~km}$ of Lake Ranobe (Dataset S2). Reliable previously published data came from introduced animals (13 total: Bos taurus indicus $n=12$ and Canis familiaris $n=1$ ) and endemic animals (44 total: Palaeopropithecus ingens $n=13$, Hippopotamus lemerlei $n=11$, Archaeolemur majori $n=7$, Megaladapis spp. $n=7$, Pachylemur insignis $n=2$, Aepyornis cf. maximus $n=1$, and the extant Lemur catta $n=3$ ). We estimated the timing of extirpation and introduction events for animals with sufficient sample sizes $(n \geq 5)$ with a Bayesian approach to event estimation applied to our ${ }^{14} \mathrm{C}$ datasets [52]. 


\subsection{Geochemical Data}

We measured weight percent carbon (TC) and nitrogen (TN) on bulk sediment samples $(n=215)$ at 1-2-cm resolution with a Carlo Erba NA $1500 \mathrm{C} / \mathrm{N} / \mathrm{S}$ Analyzer at the UF Department of Geological Sciences Stable Isotope Laboratory (Dataset S5). We determined weight percent total inorganic carbon (TIC) in bulk sediment by coulometry on a UICCoulometrics coulometer, coupled with an AutoMate automated carbonate preparation device (AutoMate FX, Inc., Bushnell, FL, USA). We subtracted TIC from TC values to obtain estimates of percent total organic carbon (TOC). We follow the standard assumption that all inorganic carbon was bound as $\mathrm{CaCO}_{3}$ and that organic carbon constitutes $\sim 44.4 \%$ of organic matter (mostly carbohydrates, e.g., $\mathrm{C}_{6} \mathrm{H}_{12} \mathrm{O}_{6}$ ) mass to calculate total percent $\mathrm{CaCO}_{3}\left(\mathrm{TIC}^{*} 8.33\right)$ and total percent organic carbon (TOC $\left.{ }^{*} 2.25\right)$, respectively. To measure $\delta^{13} \mathrm{C}$ in sediment organic matter, we first acidified samples $(n=215)$ in $1 \mathrm{~N} \mathrm{HCl}$ overnight to dissolve carbonates. Following acidification, samples were centrifuged and rinsed in DI water $3 \times$, freeze-dried, and packed in tin capsules for analysis on a Delta $V$ isotope ratio mass spectrometer (IRMS) coupled with a Carlo Erba NA 1500 elemental analyzer at UF. Nitrogen isotopes were measured on raw, dried, and ground samples. Precision of $\delta^{13} \mathrm{C}$ and $\delta^{15} \mathrm{~N}$ measurements, established by analysis of standards across runs, was $0.08 \%$ and $0.07 \%$, respectively.

To analyze lacustrine carbonate shells, we washed samples in a $150-\mu \mathrm{m}$ sieve and picked multiple monospecific ostracod shells (Bradleystrandesia cf. fuscata) from the course fraction of each of 169 samples. We analyzed samples with a Kiel carbonate device coupled with a Finnigan-MAT 252 IRMS at UF, and the precision in $\delta^{13} \mathrm{C}$ and $\delta^{18} \mathrm{O}$ measurements of standards across runs was $0.03 \%$ and $0.06 \%$, respectively. A single modern water sample collected from the surface of Ranobe during sediment coring was analyzed with a Picarro L2120-I Isotopic Water Analyzer at UF. We determined relative abundances of heavier elements in bulk sediment at PSU with an Olympus DeltaX model X-ray fluorescence (XRF, Olympus Corp., Tokyo, Japan) core scanner and Geotek multi-sensor core logger, at sample intervals of $2 \mathrm{~cm}$, exposure times of $80 \mathrm{~s}$, a voltage of $40 \mathrm{kV}$, and a current of $23 \mathrm{~mA}$. Small amounts of material in the sediment-water interface core precluded XRF analysis of deposits from above $50 \mathrm{~cm}$ depth.

The sediment core was subsampled for microcharcoal analysis every 5-6 cm. Dry sediment $(0.2-0.5 \mathrm{~g})$ was digested in $30 \mathrm{~mL}$ of $30 \% \mathrm{H}_{2} \mathrm{O}_{2}$, following the protocol of Battarbee [53]. Microcharcoal particles $(10-150 \mu \mathrm{m})$ were quantified under a microscope using a magnification of $400 \times$ (Dataset S7). Each particle was characterized as woody or herbaceous based on the presence of stomata and epidermal cells, as well as shape [54].

We used principal components analysis and a correlation matrix to identify the covariance structure in the lake sediment records, and we applied Bayesian change point analysis (BCPA, [55]) to the Lake Ranobe and other Indian Ocean records to identify significant changes in long-term mean values of measured variables. BCPA is used to identify the partition (change points) in the sequence that results in stratigraphic intervals that each have values that can be approximated reasonably well by a single mean. This approach uses the Markov Chain Monte Carlo method at each point $\mathrm{k}$ to approximate the posterior probability that $\mathrm{k}$ is a change point given the sequences of values that precede and follow the point [56]. To create Madagascar-specific composite paleoclimate records for comparison with the combined herbivore bone dataset, we interpolated records at 1-year increments (based on our age-depth model), averaged z-scores from each record, and smoothed the average z-score record with a 100-year running mean (Dataset S6). Given that the temporal resolution of the Ranobe ostracod $\delta^{18} \mathrm{O}$ record is one measurement per $\sim 8$ years, note that the record is interpolated annually only for the sake of correspondence with speleothem $\delta^{18} \mathrm{O}$ records. Due to recent evidence for asynchronous climate change across Madagascar [9], we chose to create one composite paleoclimate record using speleothem data from Asafora Cave (SW Madagascar, near Namonte in Figure 2 [9]) and create another by combining the Ranobe record with speleothem data from Anjohibe Cave (NW Madagascar [57], see notes in Dataset $\mathrm{S} 6$ regarding this composite record). We used correlation coefficients to assess 
the relationship between herbivore taxon-specific stable isotope records and composite paleoclimate record values that correspond to the mean calibrated age of the herbivore ${ }^{14} \mathrm{C}$ data. We also used Kruskal Wallis one-way ANOVAs and Dunn's method of pairwise multiple comparisons to identify differences in collagen stable isotope values among taxa. Microcharcoal particles are presented as microcharcoal influx, calculated using charcoal concentrations and bulk sedimentation rates derived from the age-depth model.

\section{Results}

\subsection{Sediment Core Chronology}

The ${ }^{14} \mathrm{C}$ ages from the Lake Ranobe core suggest that sediment deposition in the basin has been continuous since $~ 1700-1590$ cal yr BP (PSUAMS-6332, $1775 \pm 20$ BP, Dataset S3). Our final age-depth model yielded an average, long-term linear sedimentation rate of $0.13 \mathrm{~cm} / \mathrm{yr}$ (Figure 3). Sedimentation was likely slow $(0.06 \mathrm{~cm} / \mathrm{yr})$ between $155.5 \mathrm{~cm}$ and $126.5 \mathrm{~cm}$ depth ( 1150 and $630 \mathrm{cal}$ yr BP) relative to the underlying $\sim 80 \mathrm{~cm}$ of sediment $(0.14 \mathrm{~cm} / \mathrm{yr}, \sim 1680$ and $1150 \mathrm{cal} \mathrm{yr} \mathrm{BP})$ and overlying $\sim 125 \mathrm{~cm}$ of sediment $(0.18 \mathrm{~cm} /$ year, $\sim 630 \mathrm{cal}$ yr BP and present).

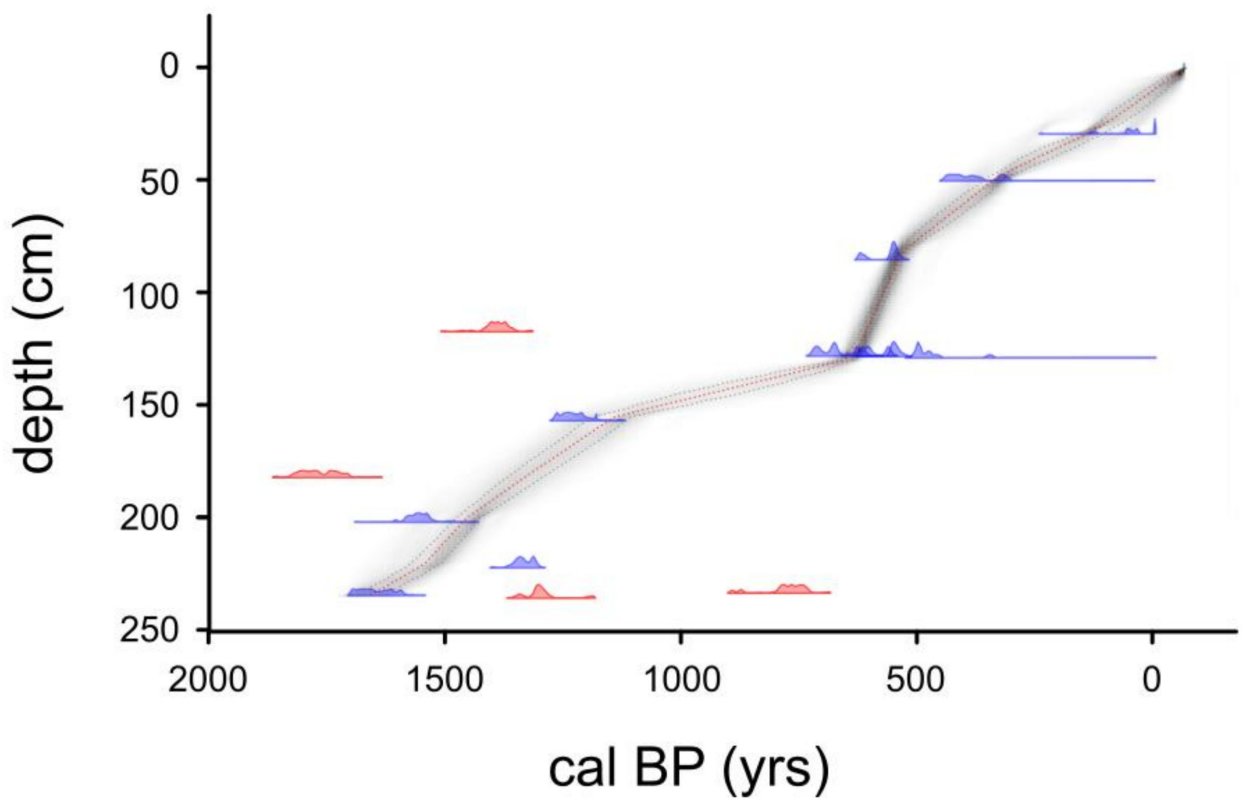

Figure 3. Lake Ranobe sediment core chronology, including probability distributions for ${ }^{14} \mathrm{C}$ dates calibrated with SHCal20 (see Dataset S3 for ${ }^{14} \mathrm{C}$ data details). The age-depth model produced in $\mathrm{R}$ Bacon v2.4.3 is based on the blue dates $(n=11)$. The red date outliers $(n=4)$ come from bulk sediment organics or aquatic plant remains, two of which might include an unknown ${ }^{14} \mathrm{C}$ reservoir effect. Apart from the ratite eggshell (PSUAMS 6332, $233.5 \mathrm{~cm}$ depth) and ostracods (PSUAMS 6334, $126.5 \mathrm{~cm}$ depth), dates used in the age-depth model come from terrestrial macrobotanical remains.

\subsection{Archaeological Survey}

Survey around the coastal ponds near Ambohimailaka recovered sparse traces of human activity, such as shell-combed ceramics and recently deposited bone, which likely span, at most, the past several hundred years. In contrast, the archaeological record from around Lake Ranobe was substantial and included large clusters of animal bones, ceramics, and marine shell (Figure 4). Marine shell was identified to taxa known to be consumed by people, and it included the crowned turban shell (Turbo coronatus), giant mangrove whelk (Terebralia palustrus), trapezium horse conch (Pleuroploca trapezium), murex snail (Chicoreus austramosus), and bearded ark clam (Barbatia foliata). The largest cluster of human artifacts, which comes from what may be considered an archaeological site, was found on the NE margin of the basin. An anomalously high concentration of historic glass in this cluster, and the shell-combed ceramics at this site, are consistent with human occupation 
during recent centuries [58]. Current inhabitants of the nearby village of Avaradrova confirmed that a settlement at this site was abandoned during the past century. We focused on ${ }^{14} \mathrm{C}$ analysis of zebu bones from clusters on the south shore of Lake Ranobe, because a variety of ceramic decorations, scarcity of historic glass, and the deflated sandy surface all suggest that these deposits span a relatively long period. Indeed, calibrated ages of eight bones from the southern margin of the lake span $\sim 500$ calibrated years ( $\sim 600-100$ mean cal yr BP, Figure 4, Dataset S2).
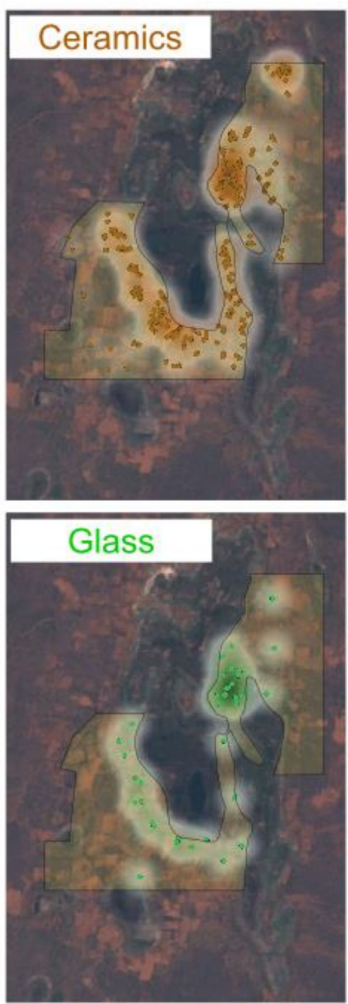
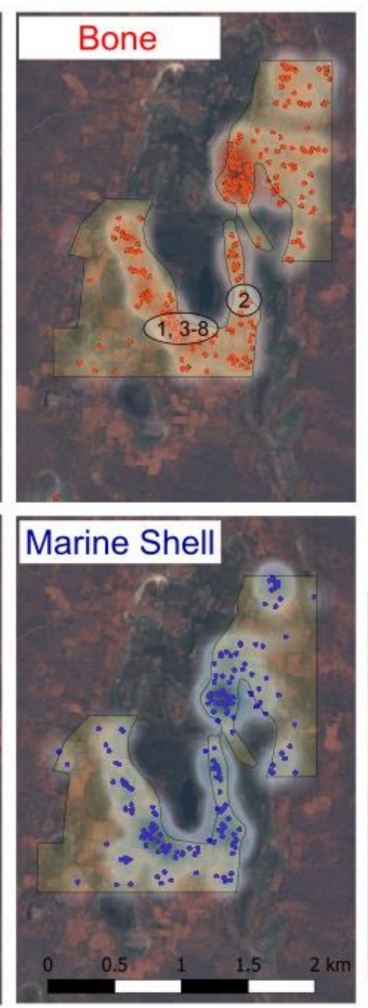

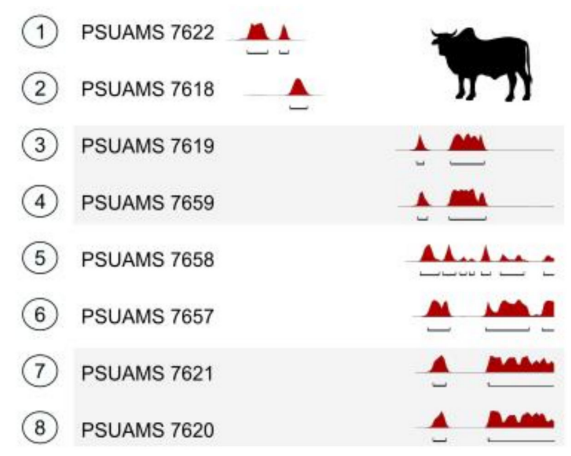

$700600500400300200100 \quad 0$

Cal BP

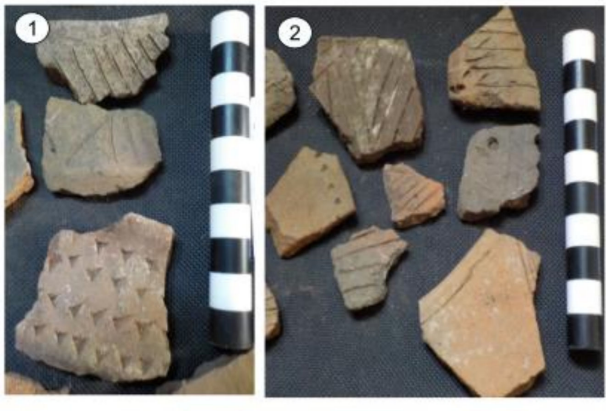

Figure 4. Distribution of surface scatters of ceramics $(n=241)$, bone $(n=252)$, glass $(n=36)$, and marine shell $(n=190)$ in the vicinity of Lake Ranobe, with point densities highlighted by heat maps. The parcel to the south yielded sparse scatters of bone $(n=13)$ and ceramics $(n=11)$ that are not shown. The calibrated ages of eight zebu bone fragments from the south shore of Lake Ranobe span the past 700 years and are associated with a variety of stamped and incised ceramics. Note that numbers in circles correspond to individual clusters of bones and ceramics.

\subsection{Geochemical Data}

Smoothed 100-year ( 12 point) running mean ostracod $\delta^{18} \mathrm{O}$ data from the sediment core display a succession of local maxima during the past $\sim 1700$ years. Values range between $-7.2 \%$ and $4.9 \%$ o $(\overline{\mathrm{x}} \pm \mathrm{SD}=-2.4 \pm 2.1 \%$ ) and are positively skewed $(0.6$, Figure 5 , Dataset S5). Surface water from Lake Ranobe, collected during September 2019, had a $\delta^{18} \mathrm{O}$ value of $-0.92 \%$. The $\delta^{18} \mathrm{O}$ value of our topmost ostracod sample $(-2.5 \%, 3 \mathrm{~cm}$ depth) is close to what would be expected given $\delta^{18} \mathrm{O}_{\text {water }}=-0.92 \%$ and $25^{\circ} \mathrm{C} \leq \mathrm{T} \leq 30^{\circ} \mathrm{C}$ (expected calcite $\delta^{18} \mathrm{O}$ range of $-2.7-3.8 \%$ ), which supports our assumption that ostracods in the lake secrete their carbonate shells near oxygen isotopic equilibrium. 

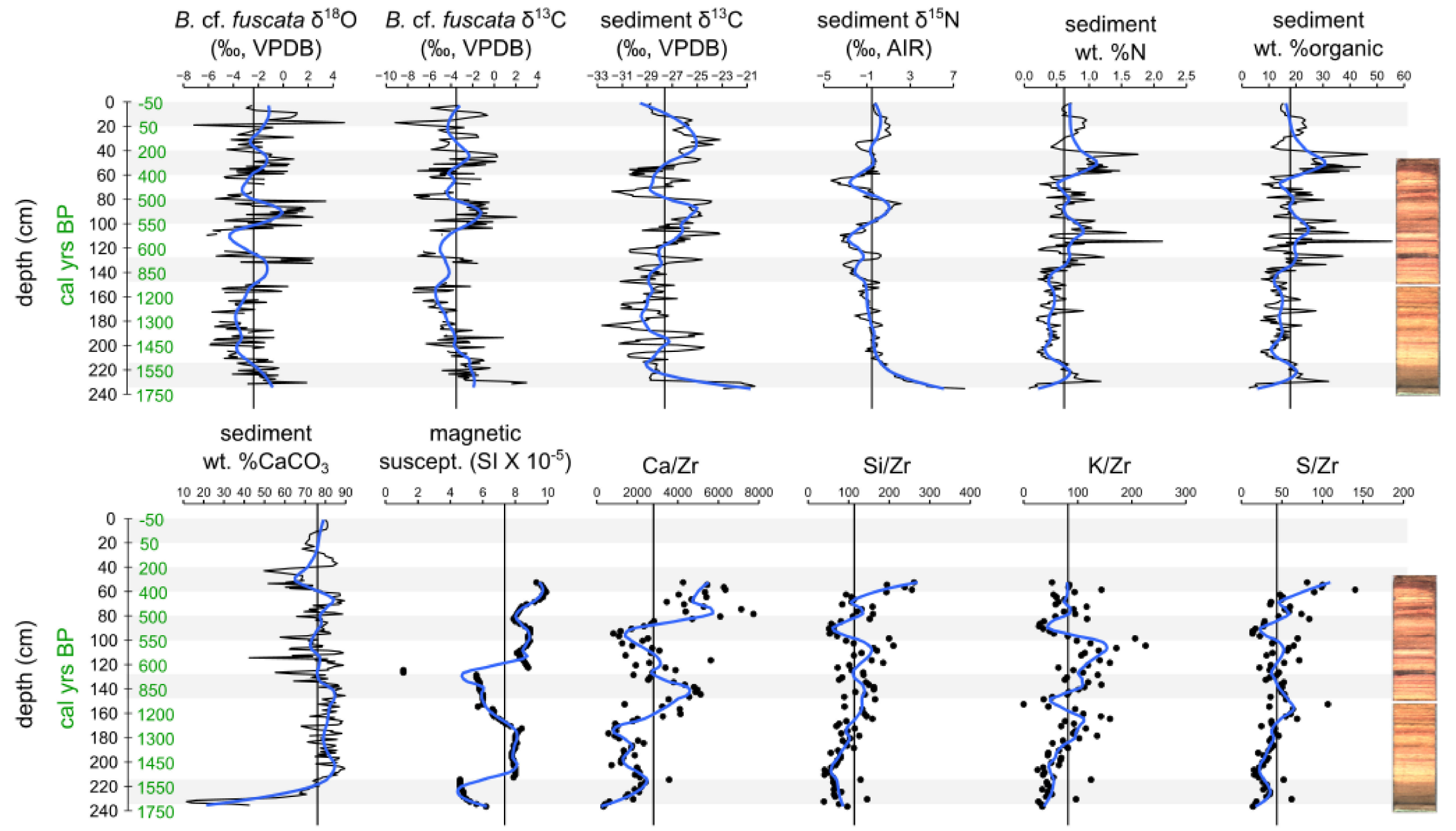

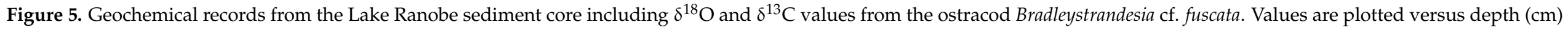

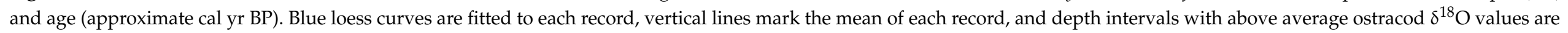
highlighted in gray. Scans of the more consolidated sediment in the deeper core sections, below $50 \mathrm{~cm}$ depth, appear at right. 
The deepest ostracod datum $\left(234.5 \mathrm{~cm}, \sim 1690 \mathrm{cal}\right.$ yr BP, $\delta^{18} \mathrm{O}=-1.0 \%$, Dataset S5) overlies relatively consolidated gray sandy mud and is at approximately the same depth as an angular fragment of ratite (flightless bird) eggshell $(233.5 \mathrm{~cm}$, PSUAMS 6332, $1775 \pm 20$ BP, Dataset S3). Sediment geochemistry varies in the overlying sediment and is associated in some cases with fluctuations in the ostracod $\delta^{18} \mathrm{O}$ record (Figure 6A). Generally, there are strong associations between (1) stable isotope values of sediment organic matter and ostracod tests (Figure 6B), and (2) among the sediment organic content and the abundances of $\mathrm{Ca}, \mathrm{K}, \mathrm{Si}$, and $\mathrm{S}$, relative to $\mathrm{Zr}$. High magnetic susceptibility is primarily associated with low sediment $\delta^{15} \mathrm{~N}$ values and is not consistently linked with sediment organic content.
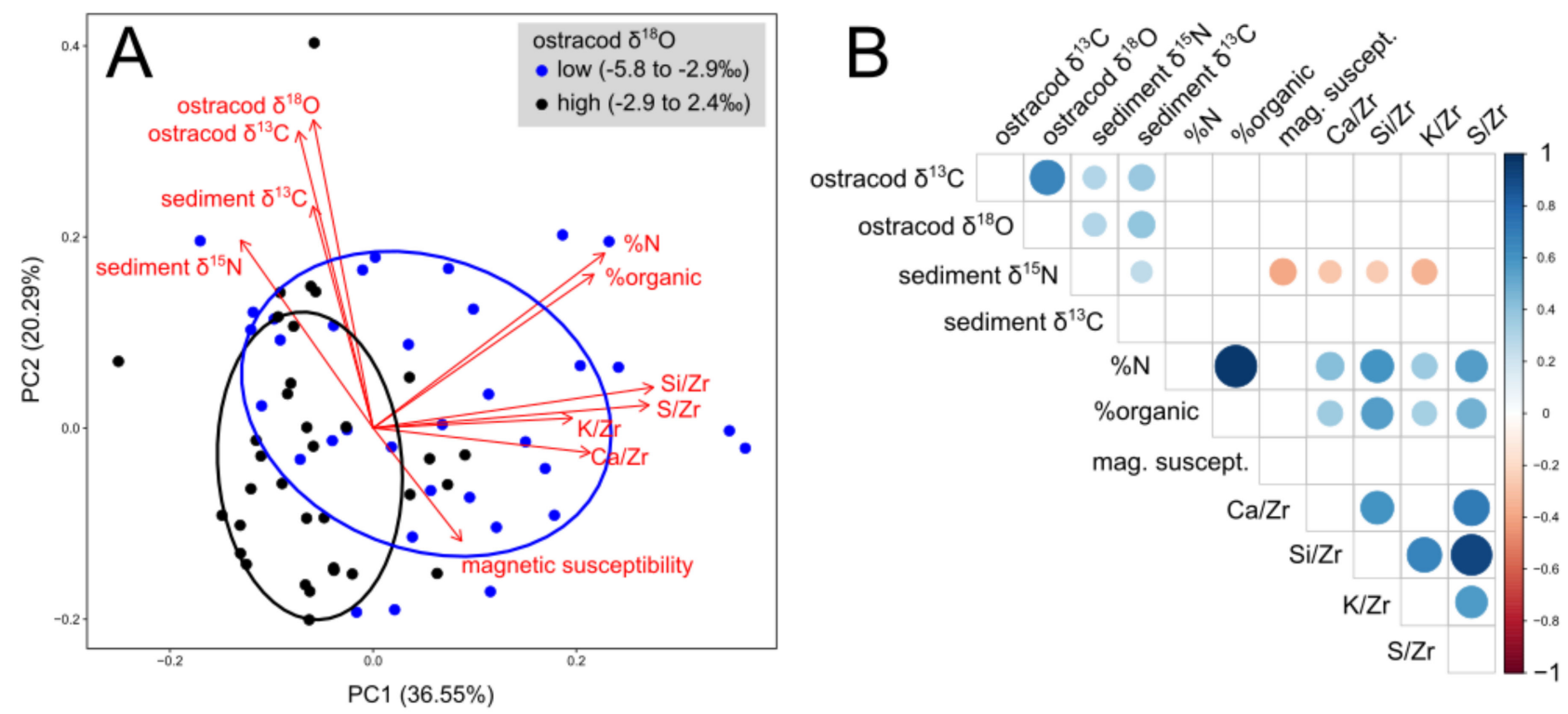

Figure 6. Principal components analysis (A) and correlation matrix (B) from the Lake Ranobe sediment core geochemical records. The PCA plot (A) includes loadings for each record in red and has samples grouped (with ellipses outlining $68 \%$ of each group) according to whether they share relatively low or high ostracod $\delta^{18} \mathrm{O}$ values. The correlation matrix (B) displays only significant correlations as circles $(p 0.05)$, with size scaled to $p$-values and color scaled to Pearson correlation coefficients (scale at right).

The base of the core includes exceptionally high organic matter $\delta^{13} \mathrm{C}$ (acidified) and $\delta^{15} \mathrm{~N}$ values (-22.9\% and 8.1\% , respectively, Dataset S5), and relatively low organic matter and $\mathrm{CaCO}_{3}$ concentrations (2.8\% and $42.6 \%$ of sediment weight, respectively). Among the heavier elements, $\mathrm{Si}, \mathrm{Zr}$, and Fe are particularly abundant at the base of the core, and Fe is mostly undetectable above $\sim 216 \mathrm{~cm}$ depth ( 1540 cal yr BP). The base of the core has relatively low magnetic susceptibility and abundant $\mathrm{Zr}$, which drives low $\mathrm{Ca} / \mathrm{Zr}, \mathrm{Si} / \mathrm{Zr}$, $\mathrm{K} / \mathrm{Zr}$, and $\mathrm{S} / \mathrm{Zr}$ values. The median $\mathrm{Si} / \mathrm{Zr}$ throughout the Lake Ranobe sediment core $(n=90, m=91.5)$ is only about $25 \%$ of that in the diatom-rich sediments of the Namonte Basin to the north, near Lake Ihotry $(n=45, m=327.0$, Mann-Whitney $\mathrm{U}=28.00, p<0.001)$. Diatoms are scarce throughout much of the Lake Ranobe core and are present in only $\sim 25 \%$ of the 30 sediment samples collected between $240 \mathrm{~cm}$ and $50 \mathrm{~cm}$ depth (M. Velez pers comm.).

The first $\sim 500$ years of sediment deposition in Lake Ranobe ( 1500-1000 cal yr BP) yielded ostracods with relatively low $\delta^{18} \mathrm{O}$ values $(-3.3 \pm 1.5 \%$ o). This sediment is composed primarily of $\mathrm{CaCO}_{3}(\sim 70-90 \mathrm{wt}$. \%) but includes some thin $(<2 \mathrm{~cm})$ dark layers that are relatively rich in $\mathrm{N}$ and organics. $\mathrm{Si} / \mathrm{Zr}, \mathrm{K} / \mathrm{Zr}$, and $\mathrm{S} / \mathrm{Zr}$ values generally increase during this interval.

The period with relatively slow linear sediment accumulation $(0.06 \mathrm{~cm} / \mathrm{yr})$ between $\sim 1150$ and 650 cal yr BP includes scarce ostracods, which precludes inference of continuous climate change. Several ostracod $\delta^{18} \mathrm{O}$ values near the top of this interval ( 700 cal yr BP), 
however, are relatively high $(\sim 2 \%)$. This interval coincides approximately with local maxima in $\mathrm{Ca} / \mathrm{Zr}$ and $\mathrm{S} / \mathrm{Zr}$ values and minima in magnetic susceptibility and $\mathrm{K} / \mathrm{Zr}$ values.

The last $\sim 700$ years of sediment deposition include approximately three maxima in ostracod $\delta^{18} \mathrm{O}$ values $(\sim 550-500, \sim 400-200$, and $\sim 50$ to -50 cal yr BP), with an average $\delta^{18} \mathrm{O}$ value across these intervals of $-1.3 \pm 2.2 \%, n=47$. The $\sim 550-500 \mathrm{cal}$ yr BP peak in ostracod $\delta^{18} \mathrm{O}$ values coincides with local minima in $\mathrm{Ca} / \mathrm{Zr}, \mathrm{Si} / \mathrm{Zr}, \mathrm{K} / \mathrm{Zr}$, and S/Zr values, and heavy element abundance data do not span the two relatively recent peaks in ostracod $\delta^{18} \mathrm{O}$ values. Aside from ostracods that date to $\sim 400-200 \mathrm{cal}$ yr BP, ostracods relatively enriched in ${ }^{18} \mathrm{O}$ come from layers that tend to have low and less variable organic content. Application of BCPA to the Lake Ranobe ostracod $\delta^{18} \mathrm{O}$ and sediment $\mathrm{Ca} / \mathrm{Zr}$ values revealed change points that coincide approximately with change points in other Indian Ocean records (Figure 7, Dataset S6, [16,59]).

\subsection{Charcoal and Herbivore Data}

The disappearance of several megafauna taxa (pygmy hippos and three extinct giant lemurs) from around Lake Ranobe coincided approximately with the appearance of cattle, a peak in sediment $\mathrm{Cu}$ concentration, and a rise in microcharcoal abundance at the nearby site of Andolonomby (Figure 8). All samples from Ranobe contained microcharcoal, and wood charcoal was up to an order of magnitude more abundant than herbaceous charcoal (Dataset S7). Although detectable throughout the record, the influx of charcoal at Ranobe peaked sharply between $\sim 590$ and 460 cal yr BP (average wood: $\sim 233,000$ particles $/\left(\mathrm{yr}^{*} \mathrm{~cm}^{-2}\right)$, herbaceous $\sim 297,000$ particles $/\left(\mathrm{yr}^{*} \mathrm{~cm}^{-2}\right)$ ). A later increase in charcoal influx $\sim 140 \mathrm{cal}$ yr BP included relatively abundant wood particles (wood: $\sim 6,810,000$ particles $/\left(\mathrm{yr}^{*} \mathrm{~cm}^{-2}\right)$, herbaceous: $~ 365,000$ particles $/\left(\mathrm{yr}^{*} \mathrm{~cm}^{-2}\right)$ ).

There are significant differences in median $\delta^{13} \mathrm{C}$ values $(\mathrm{H}(4)=49.04, p<0.001)$ and median $\delta^{15} \mathrm{~N}$ values among herbivores $(\mathrm{H}(4)=22.24, p<0.001$, Figure 9). Pairwise comparisons indicate that the median cattle $\delta^{13} \mathrm{C}$ value $(n=21, m=-7.4 \%)$ is significantly greater than values from giant lemurs Paleopropithecus ingens ( $n=14, m=-20.8 \%$ ), Archaeolemur majori $(n=7, m=-20.6 \%)$, and Megaladapis spp. $(n=7, m=-21.0 \%, p<0.001$ for each). Such comparison also shows that the median pygmy hippo $\delta^{13} \mathrm{C}$ value $(n=11$, $m=-16.6 \%$ ) is significantly greater than that of Megaladapis spp. $(n=7, m=-21.0 \%$, $p=0.04)$. Finally, the median cattle $\delta^{15} \mathrm{~N}$ value $(n=21, m=10.8 \%$ o is significantly lower than that of one species of the giant lemur, Paleopropithecus ingens ( $n=14, m=14.4 \%$, $p<0.001)$. Note that the number of modern bushpigs and goats collected around Ranobe is small ( $<3$ individuals/taxon), but the existing $\delta^{13} \mathrm{C}$ and $\delta^{15} \mathrm{~N}$ data from these taxa fall within the observed range of $\delta^{13} \mathrm{C}$ and $\delta^{15} \mathrm{~N}$ data from extinct megafauna. There are positive correlations between herbivore $\delta^{13} \mathrm{C}$ values and the composite Ranobe and Anjohibe $\delta^{18} \mathrm{O}$ z-score record for hippos $\left(n=9, r_{p}=0.80, p=0.01\right)$ and cattle $\left(n=21, r_{p}=0.49\right.$, $p=0.02$, Figure 9). Negative correlations exist between cattle $\delta^{15} \mathrm{~N}$ values and both the Ranobe-Anjohibe composite record $\left(n=21, r_{p}=-0.52, p=0.01\right)$ and the Ranobe-Asafora composite $\left(n=21, r_{p}=-0.43, p=0.05\right.$, Figure 9$)$. 


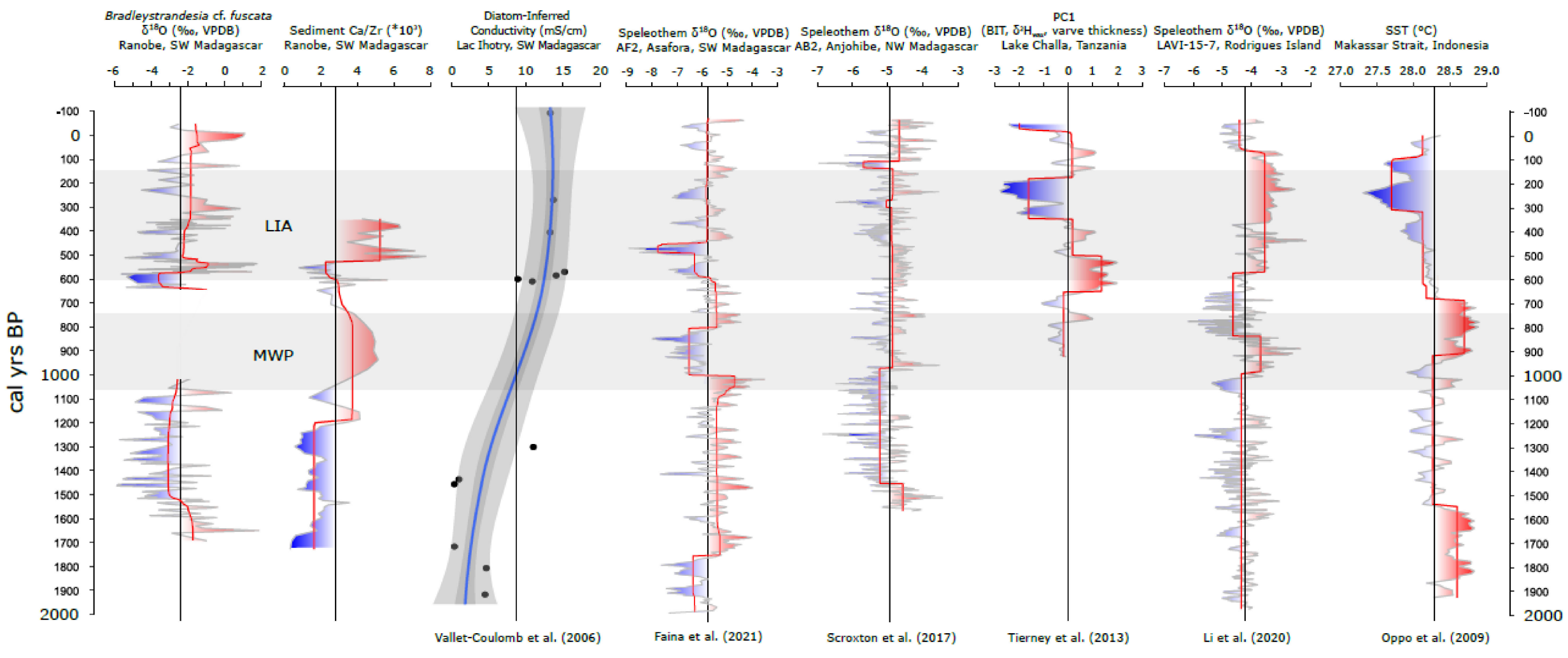

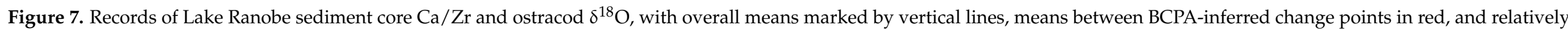

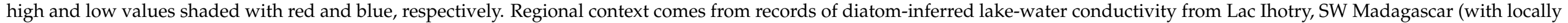

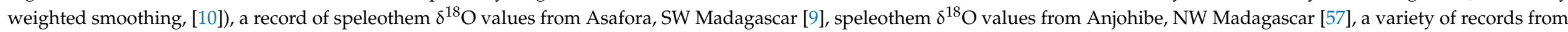

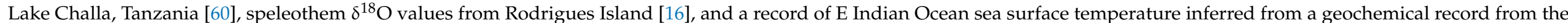
Makassar Strait [59]. Time periods that included the Medieval Warm Period (MWP) and Little Ice Age (LIA) are shaded in gray. 


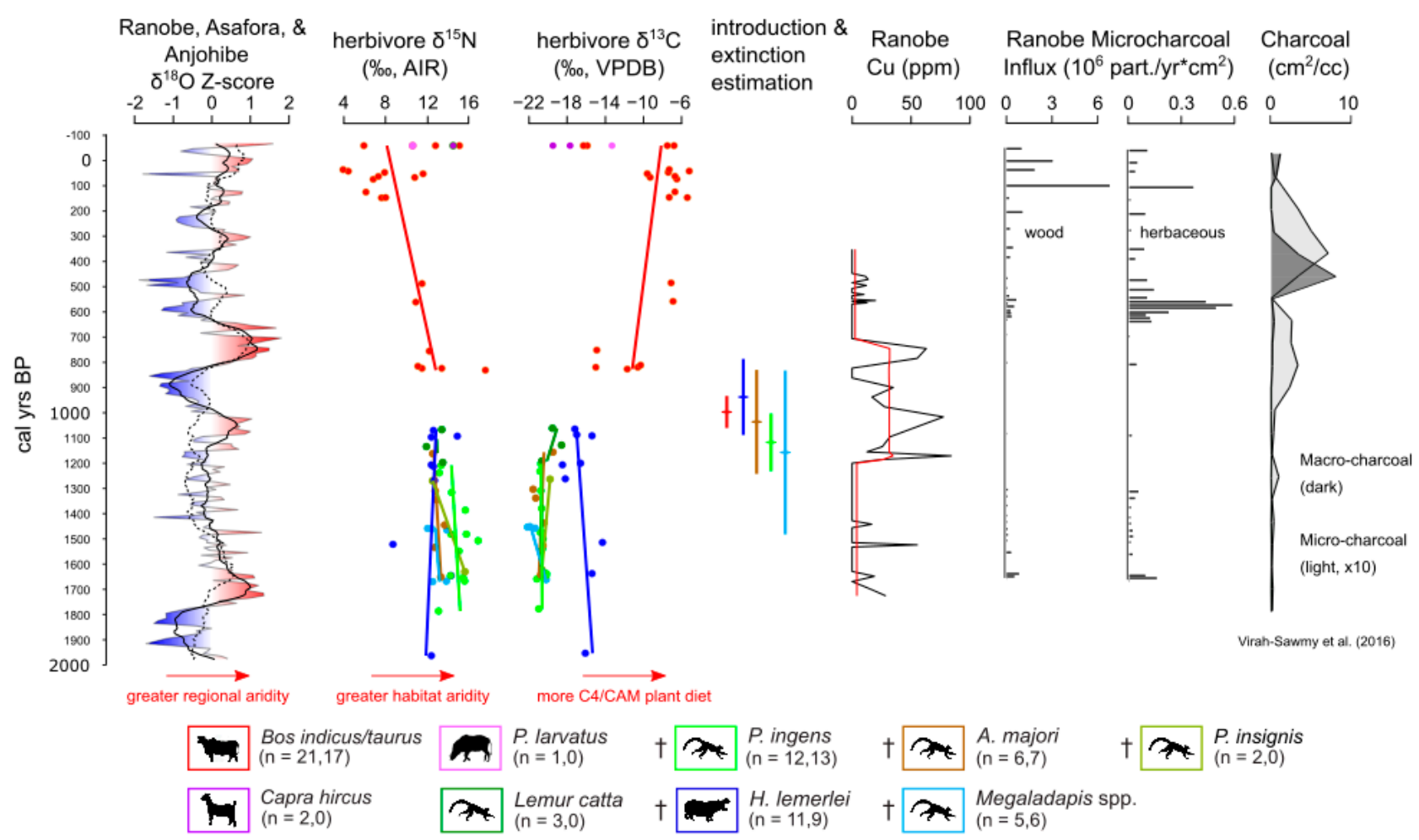

Figure 8. Composite of regional climate records, Ranobe animal bone stable isotope records, local extinction and introduction estimates, and records of Cu and charcoal deposition in lake sediments around Lake Ranobe (including Andolonomby / Ambolisatra record from Virah-Sawmy et al., 2016). To create the composite paleoclimate record, the Ranobe and Asafora $\delta^{18} \mathrm{O}$ records were interpolated at 1-year increments (using linear interpolation for the sake of matching records with different sampling intervals), z-scored, averaged, and then thinned to include 1 datum per decade (for the sake of display). The solid black line gives the 100-year smoothed Ranobe-Asafora composite, and the dashed black line gives the 100-year smoothed Ranobe-Anjohibe record. Note that the unsmoothed Ranobe-Anjohibe record is not shown for the sake of clarity and that this composite record relies exclusively on speleothem data from Rodrigues Island [16] before 1700 cal yr BP (Dataset S6). Introduced and extinct animal stable isotope data $(n=63)$ plotted over time are fitted with lines, and Bayesian event estimates $(\mu \pm \sigma)$ for extinctions and zebu cattle introduction are based on ${ }^{14} \mathrm{C}$ data $(\mathrm{n}=52)$ from taxa with $\mathrm{n}>5$. Of the endemic taxa (hippos and lemurs, with extinct taxa marked with daggers), only Lemur catta is extant. Taxon-specific sample sizes of the form ( $\mathrm{n}=$ (stable isotope sample size), $\left({ }^{14} \mathrm{C}\right.$ sample size)) reflect the fact that extinction confidence intervals for pygmy hippos and giant lemurs consider all data from individuals since $3000 \mathrm{cal} \mathrm{yr} \mathrm{BP} \mathrm{and} \mathrm{that} \mathrm{the} \mathrm{introduction} \mathrm{confidence} \mathrm{interval} \mathrm{for} \mathrm{zebu} \mathrm{cattle} \mathrm{data} \mathrm{does} \mathrm{not} \mathrm{consider} \mathrm{the} 3$ modern individuals with stable isotope data. 


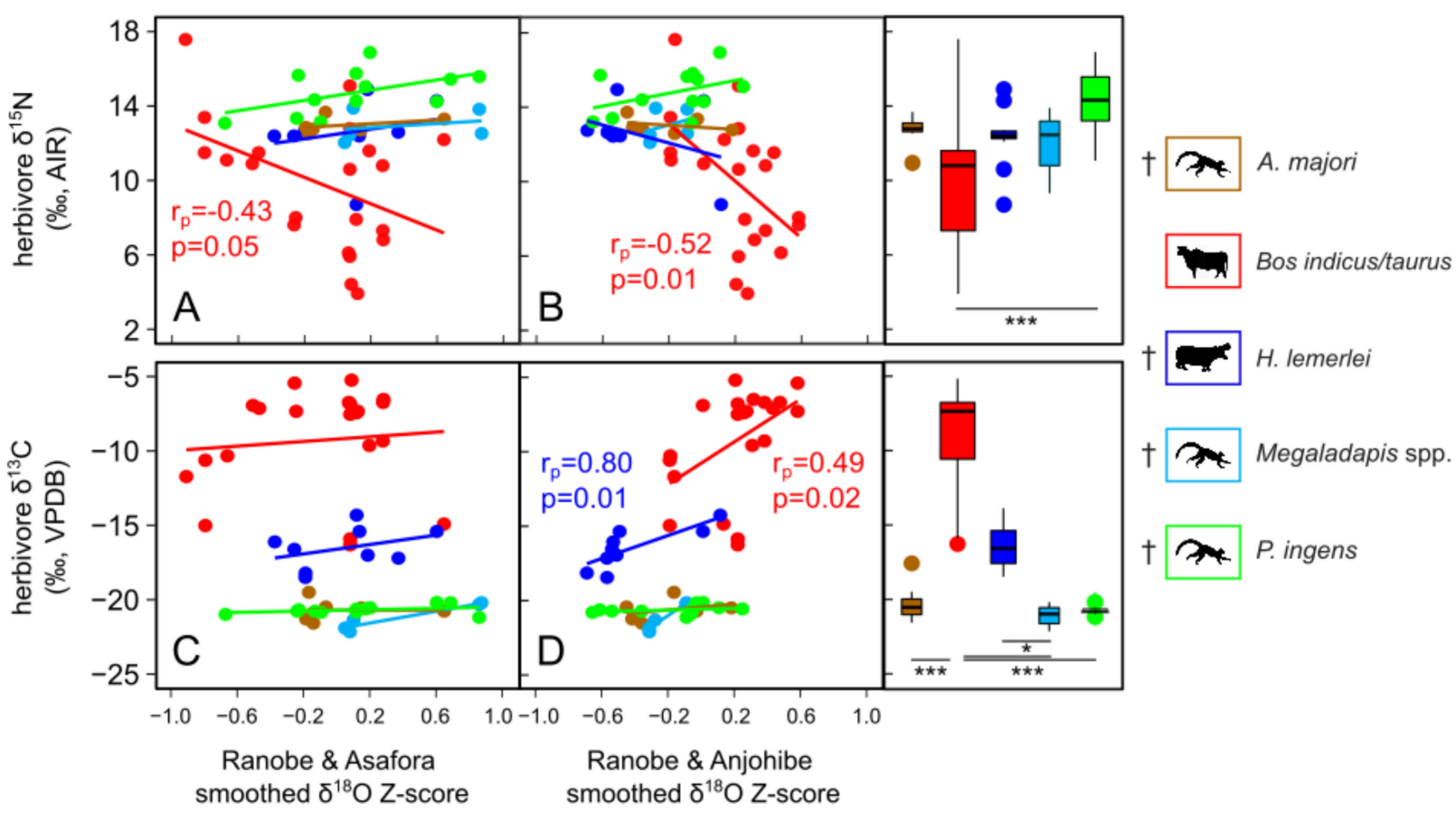

Figure 9. Herbivore $\delta^{15} \mathrm{~N}$ data $(\mathbf{A}-\mathbf{B})$ and $\delta^{13} \mathrm{C}$ data $(\mathbf{C}-\mathbf{D})$ against 100 -year smoothed paleoclimate composite records from Figure 8. Herbivore data were matched to each smoothed composite record (Ranobe-Asafora for $\mathbf{A}$ and $\mathbf{C}$, Ranobe-Anjohibe for $\mathbf{B}$ and $\mathbf{D})$ according to the mean calibrated age of individuals, and only significant $(p \leq 0.05)$ correlation coefficients are given. The associated box plots at right compare the distributions of $\delta^{15} \mathrm{~N}$ and $\delta^{13} \mathrm{C}$ values among taxa, with the width of boxes scaled according to sample size. Kruskal-Wallis one-way ANOVAs and Dunn's method of pairwise multiple comparisons suggest significant differences between taxa, with * marking $p<0.05$, and ${ }^{* * *}$ marking $p<0.001$.

\section{Discussion}

The Lake Ranobe ostracod $\delta^{18} \mathrm{O}$ values, coupled with $\mathrm{Ca} / \mathrm{Zr}$ and sedimentation rate data, indicate a dry interval $\sim 1000 \mathrm{cal}$ yr BP that approximately coincided with (1) the disappearance of endemic pygmy hippos and giant lemurs 1100 to $900 \mathrm{cal} \mathrm{yr} \mathrm{BP}$ and (2) the appearance of introduced zebu and possibly other evidence of human activities, such as forest clearance through burning, around the lake 1000 cal yr BP. Regional paleoclimate records suggest that this arid period affected other parts of the Western Indian Ocean. Ecofacts and artifacts (i.e., cattle bones and ceramics) and vegetation burning suggest human settlement on the south shore of Lake Ranobe during a relatively wet interval between $\sim 700$ and $500 \mathrm{cal} \mathrm{yr} \mathrm{BP}$, and this wet interval may have helped pastoralists expand into inland sites. Stable isotope records from animals in the vicinity of Lake Ranobe reflect different responses to past aridification and possible drought sensitivity in cattle.

In the paragraphs that follow, we further discuss relationships among Ranobe sedimentological and archaeological records before comparing these with other Indian Ocean records. We then discuss traces of past human activity around Ranobe, potential drivers of regional vegetation change, and the relative drought sensitivity of zebu cattle and endemic megafauna.

\subsection{Drought and Relationships among Paleoclimate Records}

Relatively dry periods, characterized by high E/P and low lake levels, left relatively ${ }^{18} \mathrm{O}$-enriched ostracods and associated geochemical evidence. The strong positive correlation between lacustrine carbonate $\delta^{18} \mathrm{O}$ and $\delta^{13} \mathrm{C}$ values is typical of closed basins [61] and can be explained by coupled changes in lake water $\delta^{18} \mathrm{O}$ values and the $\delta^{13} \mathrm{C}$ values of the dissolved inorganic carbon (DIC) species $\left(\mathrm{CO}_{2}, \mathrm{HCO}_{3}{ }^{-}, \mathrm{CO}_{3}{ }^{2-}\right)$ within the lake. Specifically, reduced freshwater inputs of ${ }^{13} \mathrm{C}$-depleted DIC and relatively strong evapo- 
ration (driving increased partial pressure of $\mathrm{CO}_{2}$ in the lake and increased loss of ${ }^{12} \mathrm{CO}_{2}$ to the atmosphere) can increase the $\delta^{13} \mathrm{C}$ of the remaining DIC during drought [62]. The correlation between the Lake Ranobe sediment organic matter and ostracod $\delta^{13} \mathrm{C}$ values suggests that ostracods used DIC from the lake for shell formation, and the sediment organics include primarily remains of aquatic plants that used lake DIC for photosynthesis.

Both the origin of the lake and subsequent changes in lake level can explain the association of sediment organic matter $\delta^{15} \mathrm{~N}$ and ostracod $\delta^{18} \mathrm{O}$ values. When soil $\mathrm{N}$ is in short supply, plant uptake can leave soils enriched in ${ }^{15} \mathrm{~N}$ [63], and preferential loss of ${ }^{14} \mathrm{~N}$ to the atmosphere can also leave soils enriched in ${ }^{15} \mathrm{~N}$ (particularly under arid conditions, [64]). The most recent filling of Lake Ranobe, indicated by the transition from sandy soil to calcareous lake sediment at the base of the core, preserved organic-rich lacustrine sediment with high \%N (Figure 5). Relatively low $\delta^{15} \mathrm{~N}$ values in this lacustrine sediment likely reflect diminished loss of ${ }^{14} \mathrm{~N}$ to the atmosphere and terrestrial plants. Thus, associated early increases in lake volume and changes in $\mathrm{N}$ cycling likely explain the coupled low ostracod $\delta^{18} \mathrm{O}$ values and organic matter $\delta^{15} \mathrm{~N}$ values near the base of the core ( 1600 cal yr BP, Figure 5). Subsequent, relatively small increases in sediment organic matter $\delta^{15} \mathrm{~N}$ values may reflect shallowing of the lake, which could have contributed to warmer water temperatures, reductions in dissolved oxygen, increased microbe-driven denitrification, and ${ }^{15} \mathrm{~N}$ enrichment of the lake's remaining nitrate pool $[65,66]$. The negative correlation between sediment $\delta^{15} \mathrm{~N}$ values and magnetic susceptibility may stem, in part, from greater deposition of ferromagnetic minerals via runoff during wet periods, associated with relatively low $\delta^{15} \mathrm{~N}$ values in sediment organic matter.

Variation in the organic matter content of the sediment is not consistently correlated with the stable isotope or magnetic susceptibility records, and the strong correlation between $\% \mathrm{TOC}$ and $\% \mathrm{~N}$ is expected. Relatively high $\mathrm{Si} / \mathrm{Zr}$ and $\mathrm{Ca} / \mathrm{Zr}$ values in organic-rich sediments suggest that aquatic plants and organisms with silica and carbonate skeletons flourished under similar circumstances and in many cases during times with relatively low ostracod $\delta^{18} \mathrm{O}$ values (Figures 5 and 6 ). Note, however, that both biogenic carbonate deposition during wet periods and chemical carbonate precipitation during relatively dry times can increase $\mathrm{Ca} / \mathrm{Zr}$ values and complicate interpretation of the association between $\mathrm{Ca} / \mathrm{Zr}$ and ostracod $\delta^{18} \mathrm{O}$ values $[18,19]$. Our observed correlation between $\%$ organic matter and $\mathrm{S} / \mathrm{Zr}$ may follow from sulfur deposited in organic matter or from the deposition of $\mathrm{S}$ in pyrite $\left(\mathrm{FeS}_{2}\right)$ under reducing conditions [67]. Finally, coupled $\mathrm{K} / \mathrm{Zr}$ and magnetic susceptibility values may both follow from relatively intense periods of erosion $[18,20,21]$.

\subsection{Chronology and Regional Comparison}

1700-1500 cal yr BP: Freshwater filled the inter-dune swale that defines Lake Ranobe. Lacustrine carbonates and organic matter accumulated over underlying sand and terrestrial animal remains such as Mullerornis modestus eggshell. It was unexpected to find that early deposition of lacustrine sediments in Ranobe preceded slightly the onset of dry conditions inferred from the nearby Asafora speleothem $\delta^{18} \mathrm{O}$ record ( $1550 \mathrm{cal}$ yr BP) [9]. A minimum $\delta^{18} \mathrm{O}$ value at $\sim 1650 \mathrm{cal} \mathrm{yr} \mathrm{BP}$ in a W Indian Ocean speleothem from Rodrigues Island, however, suggests the broader Western Indian Ocean region was relatively wet at the time [16]. Warm and wet conditions in that region today are connected with cooler than usual sea surface temperatures (SSTs) in the eastern Indian Ocean and western Tropical Pacific through the positive phase of the IOD [68]. A shift towards relatively low SST in the Makassar Strait, Indonesia, after $\sim 1550$ cal yr BP is consistent with a coincident wetting trend in Madagascar [59].

$1500-1000$ cal yr BP: Relatively low ostracod $\delta^{18} \mathrm{O}$ values reflect wet conditions, and a rise in $\mathrm{K} / \mathrm{Zr}$ values may reflect increased detrital input via runoff. A series of peaks in sediment organic content and steady increases in $\mathrm{Si} / \mathrm{Zr}$ and $\mathrm{S} / \mathrm{Zr}$ attest to pulses of primary production in the lake during this interval. Despite dry conditions inferred from above average speleothem $\delta^{18} \mathrm{O}$ values from Asafora [9], the continuous deposition of ostracods at Ranobe with below average $\delta^{18} \mathrm{O}$ values during this interval suggests that Ranobe remained 
continuously filled with water. During this period, wet conditions at Ranobe are consistent with below average speleothem $\delta^{18} \mathrm{O}$ values from Anjohibe, NW Madagascar [57]. Lower sedimentation rate after $\sim 1150 \mathrm{cal}$ yr BP, peaks in ostracod $\delta^{18} \mathrm{O}$ values around 1150 and $1080 \mathrm{cal}$ yr BP, a decrease in $\mathrm{K} / \mathrm{Zr}$ values $\sim 1100 \mathrm{cal}$ yr BP, and possibly the maximum in $\mathrm{Ca} / \mathrm{Zr}$ values $\sim 1150 \mathrm{cal} \mathrm{yr} \mathrm{BP}$ attest to a drying trend at the end of this interval. A maximum in Asafora speleothem $\delta^{18} \mathrm{O}$ values during $1100-1000 \mathrm{cal}$ yr BP also suggests that this was a relatively dry century in SW Madagascar. Anjohibe and Rodrigues speleothem $\delta^{18} \mathrm{O}$ values are out of phase with the Asafora record and remain low during 1100-1000 cal yr BP. However, an earlier increase in Rodrigues Island speleothem $\delta^{18} \mathrm{O}$ values between 1250 and 1150 cal yr BP suggests that other parts of the W Indian Ocean also experienced a drying trend toward the end of the millennium [16].

1000-650 cal yr BP: Relatively slow accumulation of sediment with lower organic matter content during the Medieval Warm Period attests to an interval of reduced primary productivity. A prolonged increase in $\mathrm{Ca} / \mathrm{Zr}$ values may reflect authigenic carbonate precipitation during low lake levels associated with drought. Low lake levels could explain the absence of ostracods throughout most of this interval and were approximately coincident with salinization of Lac Ihotry [10], maxima in speleothem $\delta^{18} \mathrm{O}$ values from Asafora Cave $~ 1000$ and $~ 750$ cal yr BP [9], and with palynological evidence for drought $\sim 950$ cal yr BP from elsewhere in southern Madagascar [69]. They are also consistent with indurated clay in Lac Ihotry from $\sim 800 \mathrm{cal}$ yr BP that blocked our coring efforts, and with the highest $\mathrm{Ca} / \mathrm{Zr}$ values near the base of the Lake Namonte sediment core [70]. Although lake sediments from Ranobe and elsewhere in SW Madagascar record what could have been several centuries of dry conditions, a pronounced return to below average speleothem $\delta^{18} \mathrm{O}$ values at Asafora during $\sim 950-800 \mathrm{cal}$ yr BP suggests that this interval may have been punctuated by wet conditions. Wet conditions punctuating an otherwise dry interval may be specific to SW Madagascar, for speleothem $\delta^{18} \mathrm{O}$ values peaked at Anjohibe and Rodrigues Island during 950-800 cal yr BP. Additionally, elevated SST in the Makassar Strait during 950-700 cal yr BP suggests that multidecadal dry conditions in the W Indian Ocean occurred during negative IOD-like conditions [59].

650 cal yr BP to present: The return of ostracods with relatively low $\delta^{18} \mathrm{O}$ values, along with a simultaneous decrease in $\mathrm{Ca} / \mathrm{Zr}$ and increase in magnetic susceptibility at the start of this interval, likely indicate a return to relatively mesic conditions. This is consistent with relatively low $\delta^{13} \mathrm{C}$ values in baobab tree ring cellulose from western Madagascar during $700-550$ cal yr BP [11]. This trend is also matched by relatively low Asafora speleothem $\delta^{18} \mathrm{O}$ values after $600 \mathrm{cal}$ yr BP, as well as by relatively low Rodrigues Island speleothem $\delta^{18} \mathrm{O}$ values [16] and a decline in Makassar Strait SST 700 cal yr BP [59]. Makassar Strait SST continued to decline during much of this interval and notably during the Little Ice Age [59], and a coincident transition to mesic conditions around Lake Challa (Kenya/Tanzania) suggests there were widespread positive IOD-like conditions [60]. However, peaks in the Lake Ranobe ostracod $\delta^{18} \mathrm{O}$ values, which punctuate the record since $600 \mathrm{cal}$ yr BP, suggest episodic returns to dry conditions $\sim 550, \sim 400-250$, and 50 to -50 cal yr BP. These peaks tend to be more consistent with the Asafora speleothem record than with the Anjohibe speleothem record. The $\sim 550 \mathrm{cal}$ yr BP drying is associated with organic-poor sediment with high $\delta^{15} \mathrm{~N}$ values and low $\mathrm{K} / \mathrm{Zr}, \mathrm{Si} / \mathrm{Zr}, \mathrm{Ca} / \mathrm{Zr}$, and $\mathrm{S} / \mathrm{Zr}$ values, and it is consistent with a local maximum in Asafora speleothem $\delta^{18} \mathrm{O}$ values [9], as well as with aridity recorded in baobab cellulose from western Madagascar [11], sediments from Lake Challa [60], and the Rodrigues Island speleothem [16]. The aridity $\sim 400-250 \mathrm{cal}$ yr BP coincides with two maxima in Asafora speleothem $\delta^{18} \mathrm{O}$ values [9], and the onset of this dry interval is consistent with a peak in Rodrigues Island speleothem $\delta^{18} \mathrm{O}$ values [16]. This dry interval may have been less severe than that of $\sim 550 \mathrm{cal} \mathrm{yr} \mathrm{BP}$, because the $\sim 400-250 \mathrm{cal} \mathrm{yr}$ BP interval includes relatively low ostracod $\delta^{18} \mathrm{O}$ peaks, high magnetic susceptibility, and average $\mathrm{K} / \mathrm{Zr}$ values. The ostracod $\delta^{18} \mathrm{O}$ peaks during this interval may, however, have been dampened by anthropogenic deforestation documented by Virah-Sawmy et al. [8]. Fire and forest loss could contribute to (1) faster recharge, thereby lowering lake water 
$\delta^{18} \mathrm{O}$ values, and (2) greater erosion, which would have increased $\mathrm{K} / \mathrm{Zr}$ and magnetic susceptibility during a time of comparable aridity. Unlike the most recent dry interval and that of $\sim 550$ cal yr BP, primary productivity was markedly high $\sim 400-250 \mathrm{cal} \mathrm{yr} \mathrm{BP}$, as evidenced by a peak in organic matter content (also visible in core scans as darker layers) and some of the highest $\mathrm{Si} / \mathrm{Zr}$ and $\mathrm{S} / \mathrm{Zr}$ values.

\subsection{Human Activity and Vegetation Change}

The disappearance of megafauna from around Lake Ranobe coincided with the dry interval from 1000-700 cal yr BP, yet coeval evidence for intensified human activity in the area confounds inference of extirpation driven exclusively by drought. The introduction of cattle during this interval (1080-960 cal yr BP) and regional presence of goats and bushpigs at this time could have led to multiple forms of competition between introduced and endemic megaherbivores [22]. Moreover, a coincident peak in $\mathrm{Cu}$ concentration ( 1190-900 cal yr BP) may reflect smelting for metal tool production [71,72]. Our survey recovered some slag fragments from the south shore of Lake Ranobe (loosely associated with bone that spans at least the past $~ 600$ years, Figure 4 ), and $~ 1000$-yearold lemur (Propithecus verreauxi) bones from the site of Taolambiby, $100 \mathrm{~km}$ SE of Lake Ranobe (Figure 2), include cutmarks likely produced by metal tools [73,74]. However, the microcharcoal influx peaks in the Ranobe core $(\sim 107 \mathrm{~cm}$ depth, corresponding to $600-570 \mathrm{cal}$ yr BP) lag by $\sim 550$ years the start of the peak in $\mathrm{Cu}$ concentration $(\sim 159 \mathrm{~cm}$ depth, corresponding to $1240-1160 \mathrm{cal}$ yr BP). This lag suggests that any metal tool production at $\sim 1000$ cal yr BP did not involve extensive burning near Ranobe.

Peaks in charcoal influx at Lake Ranobe at $\sim 590-460$ cal yr BP coincided with the deposition of the earliest ${ }^{14} \mathrm{C}$-dated zebu cattle from the southern margin of the lake. The high influx of herbaceous charcoal during this interval could reflect grassland management by pastoralists, for it occurred in the absence of clear evidence for dry conditions (Figure 8). Additionally, a pollen record from the nearby site of Andolonomby/Ambolisatra supports the idea that herbaceous fodder biomass became increasingly abundant after 700 cal yr BP [8]. Previous work at Andolonomby/Ambolisatra suggested that herbaceous taxa expanded and led to more widespread fires following the loss of endemic megaherbivores [34]. However, our new bone and charcoal data suggest that much of the burning in the vicinity of Ranobe followed the introduction of livestock by at least hundreds of years, regardless of the uncertainty in our sediment age-depth model. As populations of introduced herbivores became established, there was likely little relaxation of herbivory on herbaceous taxa following the extinction of endemic megafauna. Indeed, Virah-Sawmy [8] suggested that declines in pollen from herbaceous taxa within the past 200 years reflect extensive grazing, and we find support for this inference based on (1) consistently high $\delta^{13} \mathrm{C}$ values in zebu during the past several hundred years and (2) the relative scarcity of herbaceous particles in the recent charcoal influx peaks $\sim 140$ cal yr BP.

The most visible traces of early pastoralism around Ranobe (herbaceous charcoal and zebu bones) were deposited during a relatively wet interval at $\sim 600 \mathrm{cal} \mathrm{yr} \mathrm{BP} \mathrm{(Figure} 8$ ), and those wet conditions could have helped agropastoralist populations expand throughout inland drainages. Zebu bones from the south shore of Ranobe are associated with ceramics that are decorated with triangle impressions, incised parallel lines, and circular holes (Figure 4), which makes them similar to ceramics recovered from the inland archaeological site of Rezoky, a prehistoric pastoralist camp in the Mangoky Drainage (Figure 2) 140 km to the NE [75], and from some coastal archaeological sites in the Velondriake region to the north [76]. Directly ${ }^{14} \mathrm{C}$-dated zebu and ovicaprid bones from Rezoky $(n=8)$ span $\sim 730-500$ cal yr BP [22], which makes them approximately contemporary with the earliest ${ }^{14} \mathrm{C}$-dated zebu bones from the south shore of Lake Ranobe. The spread of pastoralists to Ranobe and Rezoky formed part of a regional expansion of pastoralism during the first half of the past millennium, and this could have contributed to landscape transformation involving anthropogenic burning in southern Madagascar after 600 cal yr BP [69], as well 
as earlier traces of forest clearance $\sim 1000 \mathrm{cal}$ yr BP revealed by pollen records from central Madagascar [77] and speleothem records from NW Madagascar [78].

\subsection{Herbivore Activity}

Differences among $\delta^{18} \mathrm{O}$ records within Madagascar from Ranobe, Asafora, and Anjohibe suggest that the choice of paleoclimate record affects inference of past herbivore responses to climate drying. The consistent absence of positive correlations between the composite $\delta^{18} \mathrm{O}$ records and herbivore $\delta^{15} \mathrm{~N}$ records (Figure 9A,B) suggests that none of the taxa we examined are drought-tolerant as envisioned in Figure 1. Consistent with the work of Crowley et al. [29,79] and Hixon et al. [80], we found relatively high $\delta^{15} \mathrm{~N}$ values in the collagen of extinct endemic megaherbivores and no increase through time. The earliest directly ${ }^{14} \mathrm{C}$-dated zebu from around Ranobe had $\delta^{15} \mathrm{~N}$ values comparable to those of endemic megafauna, which suggests they both exploited similarly arid habitat. However, zebu that lived during subsequent dry times had relatively low $\delta^{15} \mathrm{~N}$ values, which suggests that they exploited relatively mesic habitat. The data suggest that zebu abandoned arid habitats during relatively dry times, which may indicate sensitivity to drought and strategic reliance of pastoralists on mesic patches. This pattern is significant when both the Ranobe-Asafora and Ranobe-Anjohibe records are considered (Figure 9). Historically, pastoralists are known to have relied on mesic refuges during droughts [81]. Reliance of zebu on mesic habitat with relatively low $\delta^{15} \mathrm{~N}$ values during dry times within the past millennium suggests that the scarcity of mesic habitat did not contribute to megafaunal extinction, even in arid SW Madagascar. Future research should consider the possibility that surface water scarcity exacerbated resource competition between megafauna and introduced livestock. Taxon-specific responses to past climate change should be compared among livestock, particularly given the observation that similarity in stable isotope values leaves the possibility that introduced goats competed exploitatively with extinct endemic megaherbivores (observed here and in [22]).

Although low zebu $\delta^{15} \mathrm{~N}$ values suggest that these animals exploited relatively wet habitat, positive correlations between the Ranobe-Anjohibe composite record and $\delta^{13} \mathrm{C}$ values in zebu and hippos suggest that these animals coped with some vegetation change driven by aridification. Specifically, during relatively dry times, these animals likely consumed more ${ }^{13} \mathrm{C}$-enriched xerophytic $\mathrm{C}_{4}$ grasses and CAM succulents (Figure 9D). However, this result should be treated with caution given that it is not observed when considering the Ranobe-Asafora composite record (Figure 9C). The possibility that herbivores consumed more xerophytic plants during past drought should be evaluated through future research. Faina et al. [9] found that ${ }^{13} \mathrm{C}$-enriched vegetation flourished during relatively arid times, and anthropogenic deforestation contributed further to the rise of grasses and herbs in this region during the past millennium [8]. Today, endemic succulent vegetation (e.g., Euphorbia stenoclada) remains an important source of fodder that is maintained and used by pastoralists [82,83]. The combination of low $\delta^{15} \mathrm{~N}$ values and high $\delta^{13} \mathrm{C}$ values in zebu suggests that past drought could have constrained zebu to shrinking patches of mesic habitat but that these animals exploited xeric-adapted fodder in these mesic patches.

\subsection{Implications for Land Management and Conservation}

The details of past biodiversity change are important to modern conservation, because they can clarify whether restoration efforts are feasible $[5,84]$ and identify cases in which disturbance from human hunting and foraging in fact promotes biodiversity $[85,86]$. In Madagascar, the distinct habitat use of zebu and extinct megaherbivores (observed here and in [22]) suggests that introduced bovids may not be fulfilling the ecosystem services of extinct megafauna [87-89]. For example, unlike zebu, giant tortoises promote dispersal and germination of baobab tree seeds [90], and there are efforts to reintroduce the Aldabran giant tortoise (Aldabrachelys gigantea) to Madagascar [91,92]. Data from this and other studies that indicate consistent use of arid habitat by endemic herbivores during recent millennia [79] suggest that reintroduced giant tortoises and extant lemurs could tolerate 
projected climate drying in the absence of other stressors. Habitat fragmentation and environmental crime remain serious threats to the island's endemic biodiversity [93,94].

Our observation that zebu consistently relied on relatively mesic habitat during past dry intervals suggests that they may be sensitive to projected future drought. Though these domestic bovids fulfill different ecosystem services than did the extinct megafauna and likely have facilitated human hunting of endemic animals $[22,95,96]$, their husbandry is an essential livelihood component today and drives people to maintain forests of endemic succulent vegetation to support their herds [83]. We suggest that efforts to both conserve the spiny forests of SW Madagascar and maintain local livelihoods must support transhumance of zebu herds between mesic patches. Based on vegetation studies, Randriamalala, et al. [97] and Razanatsoa, et al. [98] also recommended facilitation of mobile pastoralism. Randriamalala, et al. [97] observed that destructive browsing of goats on endemic vegetation has fewer negative consequences for spiny forests than does woody charcoal production, which is expanding to supply growing urban populations. Razanatsoa, et al. [98] used paleoecological and paleoclimate data to show that past traditional land use-including a mix of pastoralism, farming, and foraging - in the Mikea territories north of Ranobe was more sustainable and provided greater livelihood security than contemporary land-use. In the face of ongoing drought, the intensified use of mesic habitat like that around Ranobe as a source of food, fodder, and building material [99] means that freshwater and riparian ecosystems should be the focus of conservation research [100]. Unlike Madagascar's forests, the island's wetlands have received little conservation attention, and a rapid survey of wetlands found widespread traces of disturbance [101]. Recent paleoecological work from Lake Namonte revealed dramatic changes in the freshwater ecosystem within only the past several centuries, which was associated with rapidly expanding human settlement [70].

\section{Conclusions}

Ranobe lake sediment records are generally consistent with the existing speleothem $\delta^{18} \mathrm{O}$ record from Asafora, SW Madagascar, which supports the observation that climate drying was asynchronous between northern and southern Madagascar during recent millennia. Although drought coincided approximately with Late Holocene megafaunal extinction, climate drying alone fails to explain the disappearance of diverse endemic megafauna and simultaneous spread of introduced livestock that exploited relatively wet habitat. The relatively high pygmy hippo and giant lemur collagen $\delta^{15} \mathrm{~N}$ values suggest that these animals successfully exploited arid habitat, which is inconsistent with the idea that drought forced endemic megaherbivores into dwindling patches of mesic habitat. Regional disappearance of megafauna may be better explained by the synergistic effects of forest clearance, vegetation burning, and other human disturbances such as hunting and the introduction of potential megaherbivore competitors. The data suggest that zebu cattle coped with past vegetation changes to a greater extent than pygmy hippos, but zebu may have been constrained to mesic patches during droughts. Zebu pastoralism is an essential dryland adaptation, and our findings likely reflect how people ensured access to preferred conditions for their livestock through landscape modification and mobility. The ecological history of large herbivores around Ranobe suggests that efforts to conserve the spiny forests of SW Madagascar and maintain local livelihoods should enable movement of zebu herds between mesic patches. The effects of ongoing climate drying and pastoralism on riparian and freshwater biodiversity should be the focus of future conservation research.

Supplementary Materials: The following are available online at https:/ /www.mdpi.com/article/10.3 390/cli9090138/s1, Dataset S1: survey results, Dataset S2: bone stable isotope and ${ }^{14} \mathrm{C}$ data, Dataset S3: sediment ${ }^{14} \mathrm{C}$ data, Dataset S4: sediment age-depth model, Dataset S5: sediment geochemical data, Dataset S6: composite climate record, Dataset S7: sediment charcoal data. 
Author Contributions: Conceptualization, S.W.H., M.B., B.J.C. and D.J.K.; formal analysis, S.W.H. and A.I.D.; investigation, S.W.H., J.H.C., M.B., A.I.D. and B.J.C.; resources, K.G.D., S.J.I., D.J.K.; data curation, S.W.H.; writing-original draft preparation, S.W.H.; writing-review and editing, S.W.H., J.H.C., M.B., K.G.D., A.I.D., B.J.C., S.J.I., D.J.K.; visualization, S.W.H.; supervision, D.J.K.; funding acquisition, S.W.H., J.H.C., M.B., K.G.D., B.J.C. and D.J.K. All authors have read and agreed to the published version of the manuscript.

Funding: This research was funded by the PSU Energy and Environmental Sustainability Laboratories and National Science Foundation Grants GRFP-2015213455 [S.H.], Archaeology DDRI-1838393 [D.K. and S.H.], and NSF-IES 1840968 [S.I.].

Data Availability Statement: All data produced and reviewed in this paper are published as associated Supplementary Datasets S1-S7.

Acknowledgments: For assistance during fieldwork, we thank the late Barthélémy Manjakahery (University of Toliara), Damy Delphin, and members of the Morombe Archaeological Project. Samples were collected and exported with authorization of the Ministry of Mines (permit \#001/2017), the Ministry of the Environment (permit \#208/17/MEEF/SG/DGF/DSAP/SCB.Re), the National Office for the Environment (permit \#728/17/MEEF/ONE/DG/DEE.rva), the Ministry of Higher Education and Scientific Research (permit \#211/17-MESupReS/SG/DGRS), the Ministry to the Presidency in Charge of Mines \& Petroleum (permit \#277/MPMP/SG/DIR.A.A.A) and the University of Toliara's CeDRATOM Museum. We thank Laurie Eccles (Pennsylvania State University) and Maria Velez (University of Regina) for laboratory assistance and Roger Portell (University of Florida), Liseth Perez, and multiple researchers from the Paleolim Listserv for assistance with aquatic specimen identifications. This manuscript also benefited from comments provided by Brooke Crowley (University of Cincinnati), four anonymous reviewers, and the special issue editors.

Conflicts of Interest: The authors declare no conflict of interest.

\section{References}

1. Douglass, K.; Cooper, J. Archaeology, environmental justice, and climate change on islands of the Caribbean and southwestern Indian Ocean. Proc. Natl. Acad. Sci. USA 2020, 117, 8254-8262. [CrossRef]

2. Bhalla, N. Drought Leaves 366,000 'One Step Away from Famine' in Madagascar: U.N. In Reuters. 2019. Available online: https:/ / www.reuters.com/places/africa/article/us-madagascar-aid-drought/drought-leaves-366000-one-step-away-fromfamine-in-madagascar-u-n-idUSKCN1T72HD (accessed on 30 June 2021).

3. Tadross, M.; Randriamarolaza, L.; Rabefitia, Z.; Yip, Z.K. Climate Change in Madagascar, Recent Past and Future; World Bank: Washington, DC, USA, 2008; p. 18.

4. Douglass, K.; Walz, J.; Morales, E.Q.; Marcus, R.; Myers, G.; Pollini, J. Historical perspectives on contemporary humanenvironment dynamics in southeast Africa. Conserv. Biol. 2019, 33, 260-274. [CrossRef] [PubMed]

5. Dietl, G.P.; Kidwell, S.M.; Brenner, M.; Burney, D.A.; Flessa, K.W.; Jackson, S.T.; Koch, P.L. Conservation paleobiology: Leveraging knowledge of the past to inform conservation and restoration. Annu. Rev. Earth Planet. Sci. 2015, 43, 79-103. [CrossRef]

6. Wilcox, B.A. Supersaturated island faunas: A species-age relationship for lizards on post-Pleistocene land-bridge islands. Science 1978, 199, 996-998. [CrossRef] [PubMed]

7. Hayashida, F.M. Archaeology, ecological history, and conservation. Annu. Rev. Anthropol. 2005, 34, 43-65. [CrossRef]

8. Virah-Sawmy, M.; Gillson, L.; Gardner, C.J.; Anderson, A.; Clark, G.; Haberle, S. A landscape vulnerability framework for identifying integrated conservation and adaptation pathways to climate change: The case of Madagascar's spiny forest. Landsc. Ecol. 2016, 31, 637-654. [CrossRef]

9. Faina, P.; Burns, S.J.; Godfrey, L.R.; Crowley, B.E.; Scroxton, N.; McGee, D.; Sutherland, M.R.; Ranivoharimanana, L. Comparing the paleoclimates of northwestern and southwestern Madagascar during the late Holocene: Implications for the role of climate in megafaunal extinction. Malagasy Nat. 2021, 15.

10. Vallet-Coulomb, C.; Gasse, F.; Robison, L.; Ferry, L.; Van Campo, E.; Chalie, F. Hydrological modeling of tropical closed Lake Ihotry (SW Madagascar): Sensitivity analysis and implications for paleohydrological reconstructions over the past 4000 years. $J$. Hydrol. 2006, 331, 257-271. [CrossRef]

11. Razanatsoa, E. Impact of Human Land-Use and Rainfall Variability in Tropical Dry Forests of Southwest Madagascar during the Late Holocene; University of Cape Town: Cape Town, South Africa, 2019.

12. Wells, N. Some hypotheses on the Mesozoic and Cenozoic paleoenvironmental history of Madagascar. In The Natural History of Madagascar; Goodman, S., Benstead, J., Eds.; University of Chicago Press: Chicago, IL, USA, 2003; pp. 16-34.

13. Saji, N.; Yamagata, T. Possible impacts of Indian Ocean dipole mode events on global climate. Clim. Res. 2003, 25, 151-169. [CrossRef]

14. Battistini, R. Conditions de gisements des sites littoraux de subfossiles et causes de la disparition de la faune des grands animaux dans le sud-ouest et l'extrême sud de Madagascar. Taloha 1971, 4, 7-18. 
15. Camoin, G.; Montaggioni, L.; Braithwaite, C. Late glacial to post glacial sea levels in the Western Indian Ocean. Mar. Geol. 2004, 206, 119-146. [CrossRef]

16. Li, H.; Sinha, A.; Andre, A.A.; Spoetl, C.; Vonhof, H.; Meunier, A.; Kathayat, G.; Duan, P.; Voarintsoa, N.R.G.; Ning, Y.; et al. A multimillennial climatic context for the megafaunal extinctions in Madagascar and Mascarene Islands. Sci. Adv. 2020, 6, eabb2459. [CrossRef]

17. Curtis, J.H.; Hodell, D.A.; Brenner, M. Climate variability on the Yucatan Peninsula (Mexico) during the past 3500 years, and implications for Maya cultural evolution. Quat. Res. 1996, 46, 37-47. [CrossRef]

18. Kylander, M.E.; Ampel, L.; Wohlfarth, B.; Veres, D. High-resolution X-ray fluorescence core scanning analysis of Les Echets (France) sedimentary sequence: New insights from chemical proxies. J. Quat. Sci. 2011, 26, 109-117. [CrossRef]

19. Haberzettl, T.; Corbella, H.; Fey, M.; Janssen, S.; Luecke, A.; Mayr, C.; Ohlendorf, C.; Schaebitz, F.; Schleser, G.H.; Wille, M.; et al. Lateglacial and Holocene wet-Dry cycles in southern Patagonia: Chronology, sedimentology and geochemistry of a lacustrine record from Laguna Potrok Aike, Argentina. Holocene 2007, 17, 297-310. [CrossRef]

20. Piva, A.; Asioli, A.; Schneider, R.R.; Trincardi, F.; Andersen, N.; Colomenero-Hidalgo, E.; Dennielou, B.; Flores, J.A.; Vigliotti, L. Climatic cycles as expressed in sediments of the PROMESS1 borehole PRAD1-2, central Adriatic, for the last 370 ka: 1 . Integrated stratigraphy. Geochem. Geophys. Geosyst. 2008, 9. [CrossRef]

21. Aufgebauer, A.; Panagiotopoulos, K.; Wagner, B.; Schaebitz, F.; Viehberg, F.A.; Vogel, H.; Zanchetta, G.; Sulpizio, R.; Leng, M.J.; Damaschke, M. Climate and environmental change in the Balkans over the last 17 ka recorded in sediments from Lake Prespa (Albania/FYR of Macedonia/Greece). Quat. Int. 2012, 274, 122-135. [CrossRef]

22. Hixon, S.W.; Douglass, K.G.; Crowley, B.E.; Rakotozafy, L.M.A.; Clark, G.; Anderson, A.; Haberle, S.; Ranaivoarisoa, J.F.; Buckley, M.; Fidiarisoa, S.; et al. Late Holocene spread of pastoralism coincides with endemic megafaunal extinction on Madagascar. Proc. R. Soc. Lond. B 2021, 288, 20211204.

23. Feldt, T.; Schlecht, E. Analysis of GPS trajectories to assess spatio-temporal differences in grazing patterns and land use preferences of domestic livestock in southwestern Madagascar. Pastoralism 2016, 6, 5. [CrossRef]

24. Burney, D.A. Climate Change and Fire Ecology as Factors in the Quaternary Biogeography of Madagascar. In Biogeography of Madagascar; Lourenco, W.R., Ed.; OSTROM: Paris, France, 1996; pp. 49-58.

25. Godfrey, L.R.; Scroxton, N.; Crowley, B.E.; Burns, S.J.; Sutherland, M.R.; Perez, V.R.; Faina, P.; McGee, D.; Ranivoharimanana, L. A new interpretation of Madagascar's megafaunal decline: The "Subsistence Shift Hypothesis". J. Hum. Evol. 2019, 130, 126-140. [CrossRef] [PubMed]

26. Burney, D.A.; Robinson, G.S.; Burney, L.P. Sporormiella and the late Holocene extinctions in Madagascar. Proc. Natl. Acad. Sci. USA 2003, 100, 10800-10805. [CrossRef] [PubMed]

27. Farquhar, G.D.; Ehleringer, J.R.; Hubick, K.T. Carbon isotope discrimination and photosynthesis. Annu. Rev. Plant Biol. 1989, 40, 503-537. [CrossRef]

28. Crowley, B.E.; Samonds, K.E. Stable carbon isotope values confirm a recent increase in grasslands in northwestern Madagascar. Holocene 2013, 23, 1066-1073. [CrossRef]

29. Crowley, B.E.; Godfrey, L.R.; Bankoff, R.J.; Perry, G.H.; Culleton, B.J.; Kennett, D.J.; Sutherland, M.R.; Samonds, K.E.; Burney, D.A. Island-wide aridity did not trigger recent megafaunal extinctions in Madagascar. Ecography 2017, 40, 901-912. [CrossRef]

30. Crowley, B.E.; Thoren, S.; Rasoazanabary, E.; Vogel, E.R.; Barrett, M.A.; Zohdy, S.; Blanco, M.B.; McGoogan, K.C.; ArrigoNelson, S.J.; Irwin, M.T.; et al. Explaining geographical variation in the isotope composition of mouse lemurs (Microcebus). J. Biogeogr. 2011, 38, 2106-2121. [CrossRef]

31. Dewar, R.E.; Richard, A.F. Evolution in the hypervariable environment of Madagascar. Proc. Natl. Acad. Sci. USA 2007, 104, 13723-13727. [CrossRef]

32. Grandidier, G. Les animaux disparus de Madagascar. Gisements, époques et causes de leur disparition. Revue de Madagascar 1905, 7, 111-128.

33. Chanudet, C. Conditions géographiques et archéologiques de la disparition des subfossiles à Madagascar. In Mémoire de Maîtrise; Université de Bretagne Occidentale: Brest, France, 1975.

34. Burney, D.A. Late Holocene environmental changes in arid southwestern Madagascar. Quat. Res. 1993, 40, 98-106. [CrossRef]

35. MacPhee, R.D.; Burney, D.A. Dating of modified femora of extinct dwarf Hippopotamus from southern Madagascar: Implications for constraining human colonization and vertebrate extinction events. J. Archaeol. Sci. 1991, 18, 695-706. [CrossRef]

36. Battistini, R.; Vérin, P. Témoignages archéologiques sur la côte vezo de l'embouchure de l'Onilahy à la Baie des Assassins. Taloha 1971, 4, 51-63.

37. Fisher, M.M.; Brenner, M.; Reddy, K.R. A simple, inexpensive piston corer for collecting undisturbed sediment/water interface profiles. J. Paleolimnol. 1992, 7, 157-161. [CrossRef]

38. Hogg, A.G.; Heaton, T.J.; Hua, Q.; Palmer, J.G.; Turney, C.S.M.; Southon, J.; Bayliss, A.; Blackwell, P.G.; Boswijk, G.; Ramsey, C.B.; et al. SHCal20 Southern Hemisphere calibration, 0-55,000 years cal BP. Radiocarbon 2020, 62, 1-20. [CrossRef]

39. Blaauw, M.; Christen, J.A. Flexible paleoclimate age-depth models using an autoregressive gamma process. Bayesian Anal. 2011, 6, 457-474. [CrossRef]

40. Philippsen, B. The freshwater reservoir effect in radiocarbon dating. Herit. Sci. 2013, 1, 24. [CrossRef]

41. Guiry, E.J.; Szpak, P.; Richards, M.P. Effects of lipid extraction and ultrafiltration on stable carbon and nitrogen isotopic compositions of fish bone collagen. Rapid Commun. Mass Spectrom. 2016, 30, 1591-1600. [CrossRef] [PubMed] 
42. Brown, T.A.; Nelson, D.E.; Vogel, J.S.; Southon, J.R. Improved collagen extraction by modified Longin method. Radiocarbon 1988, 30, 171-177. [CrossRef]

43. McClure, S.B.; Puchol, O.G.; Culleton, B.J. AMS dating of human bone from Cova de la Pastora: New evidence of ritual continuity in the prehistory of eastern Spain. Radiocarbon 2010, 52, 25-32. [CrossRef]

44. Kennett, D.J.; Plog, S.; George, R.J.; Culleton, B.J.; Watson, A.S.; Skoglund, P.; Rohland, N.; Mallick, S.; Stewardson, K.; Kistler, L.; et al. Archaeogenomic evidence reveals prehistoric matrilineal dynasty. Nat. Commun. 2017, 8, 1-9. [CrossRef]

45. Stafford, T.W.; Brendel, K.; Duhamel, R.C. Radiocarbon, $13 \mathrm{C}$ and $15 \mathrm{~N}$ analysis of fossil bone: Removal of humates with XAD-2 resin. Geochim. Et Cosmochim. Acta 1988, 52, 2257-2267. [CrossRef]

46. Stafford, T.W.; Hare, P.E.; Currie, L.; Jull, A.J.T.; Donahue, D.J. Accelerator radiocarbon dating at the molecular level. J. Archaeol. Sci. 1991, 18, 35-72. [CrossRef]

47. Lohse, J.C.; Culleton, B.J.; Black, S.L.; Kennett, D.J. A Precise Chronology of Middle to Late Holocene Bison Exploitation in the Far Southern Great Plains. J. Tex. Archaeol. Hist. 2014, 1, 94-126. [CrossRef]

48. Beaumont, W.; Beverly, R.; Southon, J.; Taylor, R.E. Bone preparation at the KCCAMS laboratory. Nucl. Instrum. Methods Phys. Res. Sect. B Beam Interact. Mater. Atoms 2010, 268, 906-909. [CrossRef]

49. DeNiro, M.J. Postmortem preservation and alteration of in vivo bone collagen isotope ratios in relation to palaeodietary reconstruction. Nature 1985, 317, 806-809. [CrossRef]

50. Van Klinken, G.J. Bone collagen quality indicators for palaeodietary and radiocarbon measurements. J. Archaeol. Sci. 1999, 26, 687-695. [CrossRef]

51. Crowley, B.E.; Godfrey, L.R. Why all those spines?: Anachronistic defences in the Didiereoideae against now extinct lemurs. S. Afr. J. Sci. 2013, 109, 1-7. [CrossRef]

52. Buck, C.E.; Bard, E. A calendar chronology for Pleistocene mammoth and horse extinction in North America based on Bayesian radiocarbon calibration. Quat. Sci. Rev. 2007, 26, 2031-2035. [CrossRef]

53. Battarbee, R.W. The Eutrophication of Lough Erne Inferred from Changes in the Diatom Assemblages of ${ }^{210} \mathrm{~Pb}-\mathrm{and}{ }^{137} \mathrm{Cs}-\mathrm{Dated}$ Sediment Cores. Proc. R. Ir. Acad. Sect. B Biol. Geol. Chem. Sci. 1986, 141-168.

54. Walsh, M.K.; Prufer, K.M.; Culleton, B.J.; Kennett, D.J. A late Holocene paleoenvironmental reconstruction from Agua Caliente, southern Belize, linked to regional climate variability and cultural change at the Maya polity of Uxbenká. Quat. Res. 2014, 82, 38-50. [CrossRef]

55. Erdman, C.; Emerson, J.W. bcp: An R package for performing a Bayesian analysis of change point problems. J. Stat. Softw. 2007, 23, 1-13. [CrossRef]

56. Barry, D.; Hartigan, J.A. A Bayesian analysis for change point problems. J. Am. Stat. Assoc. 1993, 88, 309-319.

57. Scroxton, N.; Burns, S.J.; McGee, D.; Hardt, B.; Godfrey, L.R.; Ranivoharimanana, L.; Faina, P. Hemispherically in-phase precipitation variability over the last 1700 years in a Madagascar speleothem record. Quat. Sci. Rev. 2017, 164, 25-36. [CrossRef]

58. Douglass, K. The Diversity of Late Holocene Shellfish Exploitation in Velondriake, Southwest Madagascar. J. Isl. Coast. Archaeol. 2016, 12, 1-27. [CrossRef]

59. Oppo, D.W.; Rosenthal, Y.; Linsley, B.K. 2,000-year-long temperature and hydrology reconstructions from the Indo-Pacific warm pool. Nature 2009, 460, 1113. [CrossRef]

60. Tierney, J.E.; Smerdon, J.E.; Anchukaitis, K.J.; Seager, R. Multidecadal variability in East African hydroclimate controlled by the Indian Ocean. Nature 2013, 493, 389. [CrossRef]

61. Talbot, M. A review of the palaeohydrological interpretation of carbon and oxygen isotopic ratios in primary lacustrine carbonates. Chem. Geol. Isot. Geosci. Sect. 1990, 80, 261-279. [CrossRef]

62. Li, H.-C.; Ku, T.-L. $\delta^{13} \mathrm{C}-\delta^{18} \mathrm{O}$ covariance as a paleohydrological indicator for closed-basin lakes. Palaeogeogr. Palaeoclimatol. Palaeoecol. 1997, 133, 69-80. [CrossRef]

63. Amundson, R.; Austin, A.T.; Schuur, E.A.G.; Yoo, K.; Matzek, V.; Kendall, C.; Uebersax, A.; Brenner, D.; Baisden, W.T. Global patterns of the isotopic composition of soil and plant nitrogen. Glob. Biogeochem. Cycles 2003, 17. [CrossRef]

64. Austin, A.T.; Vitousek, P. Nutrient dynamics on a precipitation gradient in Hawai'i. Oecologia 1998, 113, 519-529. [CrossRef]

65. Hecky, R.E.; Bootsma, H.A.; Mugidde, R.M.; Bugenyi, F.W.B. Phosphorus Pumps, Nitrogen Sinks, and Silicon Drains: Plumbing Nutrients in the African Great Lakes. In The Limnology, Climatology, and Paleoclimatology of the East African Lakes; Johnson, T.C., Odada, E.O., Whittaker, K.T., Eds.; Routledge: Oxfordshire, UK, 1996.

66. Talbot, M.R. Nitrogen isotopes in palaeolimnology. In Tracking Environmental Change Using Lake Sediments; Last, W.M., Smol, J.P., Eds.; Springer: Berlin/Heidelberg, Germany, 2002; Volume 2, pp. 401-439.

67. Moreno, A.; Giralt, S.; Valero-Garces, B.; Saez, A.; Bao, R.; Prego, R.; Pueyo, J.J.; Gonzalez-Samperiz, P.; Taberner, C. A 14 kyr record of the tropical Andes: The Lago Chungará sequence (18 S, northern Chilean Altiplano). Quat. Int. 2007, $161,4-21$. [CrossRef]

68. Li, T.; Wang, B.; Chang, C.P.; Zhang, Y. A theory for the Indian Ocean dipole-zonal mode. J. Atmos. Sci. 2003, 60, 2119-2135. [CrossRef]

69. Virah-Sawmy, M.; Willis, K.J.; Gillson, L. Evidence for drought and forest declines during the recent megafaunal extinctions in Madagascar. J. Biogeogr. 2010, 37, 506-519. [CrossRef]

70. Domic, A.I. Influence of late Holocene climate change, megafaunal extinction, and human occupation on terrestrial and aquatic ecosystems in SW Madagascar. Front. Ecol. Evol. 2021. submitted. 
71. Guyard, H.; Chapron, E.; St-Onge, G.; Anselmetti, F.S.; Arnaud, F.; Magand, O.; Francus, P.; Melieres, M.A. High-altitude varve records of abrupt environmental changes and mining activity over the last 4000 years in the Western French Alps (Lake Bramant, Grandes Rousses Massif). Quat. Sci. Rev. 2007, 26, 2644-2660. [CrossRef]

72. Davies, S.J.; Metcalfe, S.E.; MacKenzie, A.B.; Newton, A.J.; Endfield, G.H.; Farmer, J.G. Environmental changes in the Zirahuén Basin, Michoacán, Mexico, during the last 1000 years. J. Paleolimnol. 2004, 31, 77-98. [CrossRef]

73. Anderson, A.; Clark, G.; Haberle, S.; Higham, T.; Nowak-Kemp, M.; Prendergast, A.; Radimilahy, C.; Rakotozafy, L.M.; Ramilisonina; Schwenninger, J.L.; et al. New evidence of megafaunal bone damage indicates late colonization of Madagascar. PLoS ONE 2018, 13, e0204368. [CrossRef] [PubMed]

74. Perez, V.R.; Godfrey, L.R.; Nowak-Kemp, M.; Burney, D.A.; Ratsimbazafy, J.; Vasey, N. Evidence of early butchery of giant lemurs in Madagascar. J. Hum. Evol. 2005, 49, 722-742. [CrossRef]

75. Verin, P.; Battistini, R. Les anciens habitats de Rezoky et d'Asambalahy. Taloha 1971, 4, $29-49$.

76. Douglass, K.M.G. An Archaeological Investigation of Settlement and Resource Exploitation Patterns in the Velondriake Marine Protected Area, Southwest Madagascar, ca. 900 BC to AD 1900; Yale University: New Haven, CT, USA, 2016.

77. Burney, D.A. Late Holocene vegetational change in central Madagascar. Quat. Res. 1987, 28, 130-143. [CrossRef]

78. Burns, S.J.; Godfrey, L.R.; Faina, P.; McGee, D.; Hardt, B.; Ranivoharimanana, L.; Randrianasy, J. Rapid human-induced landscape transformation in Madagascar at the end of the first millennium of the Common Era. Quat. Sci. Rev. 2016, 134, 92-99. [CrossRef]

79. Crowley, B.E.; Godfrey, L.R.; Guilderson, T.P.; Zermeno, P.; Koch, P.L.; Dominy, N.J. Extinction and ecological retreat in a community of primates. Proc. R. Soc. Lond. B Biol. Sci. 2012, 279, 3597-3605. [CrossRef]

80. Hixon, S.W.; Smith, E.A.E.; Crowley, B.E.; Perry, G.H.; Randrianasy, J.; Ranaivoarisoa, J.F.; Kennett, D.J.; Newsome, S.D. Nitrogen isotope $\left(\delta^{15} \mathrm{~N}\right)$ patterns for amino acids in lemur bones are inconsistent with aridity driving megafaunal extinction in south-western Madagascar. J. Quat. Sci. 2018, 33, 958-968. [CrossRef]

81. Rasolondrainy, T.V.R. Decision-Making in the Face of Unpredictable Climate and Intergroup Conflicts in Southwest Madagascar, Sixteenth to Nineteenth Centuries CE; Yale University: New Haven, CT, USA, 2019.

82. Feldt, T.; Antsonantenainarivony, O.; Schlecht, E. Feed selection on dry rangelands in southwestern Madagascar: Implications for ruminant nutrition in view of ecological and social challenge. J. Arid. Environ. 2017, 144, 81-90. [CrossRef]

83. Kaufmann, J.C.; Tsirahamba, S. Forests and thorns: Conditions of change affecting Mahafale pastoralists in southwestern Madagascar. Conserv. Soc. 2006, 4, 231-261.

84. Nogué, S.; de Nascimento, L.; Froyd, C.A.; Wilmshurst, J.M.; de Boer, E.J.; Coffey, E.E.D.; Whittaker, R.J.; Fernandez-Palacios, J.M.; Willis, K.J. Island biodiversity conservation needs palaeoecology. Nat. Ecol. Evol. 2017, 1, 1-9. [CrossRef]

85. Castilla, J.C. Coastal marine communities: Trends and perspectives from human-exclusion experiments. Trends Ecol. Evol. 1999, 14, 280-283. [CrossRef]

86. Bird, R.B.; Bird, D.W.; Codding, B.F.; Parker, C.H.; Jones, J.H. The "fire stick farming" hypothesis: Australian Aboriginal foraging strategies, biodiversity, and anthropogenic fire mosaics. Proc. Natl. Acad. Sci. USA 2008, 105, 14796-14801. [CrossRef] [PubMed]

87. Crowley, B.E.; Godfrey, L.R.; Irwin, M.T. A glance to the past: Subfossils, stable isotopes, seed dispersal, and lemur species loss in southern Madagascar. Am. J. Primatol. 2011, 73, 25-37. [CrossRef] [PubMed]

88. Godfrey, L.R.; Jungers, W.L.; Schwartz, G.T.; Irwin, M.T. Ghosts and Orphans. In Elwyn Simons: A Search for Origins; Springer: Berlin/Heidelberg, Germany, 2008; pp. 361-395.

89. Federman, S.; Dornburg, A.; Daly, D.C.; Downie, A.; Perry, G.H.; Yoder, A.D.; Sargis, E.J.; Richard, A.F.; Donoghue, M.J.; Baden, A.L. Implications of lemuriform extinctions for the Malagasy flora. Proc. Natl. Acad. Sci. USA 2016, 113, 5041-5046. [CrossRef]

90. Andriantsaralaza, S.; Pedrono, M.; Tassin, J.; Roger, E.; Rakouth, B.; Danthu, P. The role of extinct giant tortoises in the germination of extant baobab Adansonia rubrostipa seeds in Madagascar. Afr. J. Ecol. 2014, 52, 246-249. [CrossRef]

91. Pedrono, M.; Rambeloson, E.; Clausen, A. Giant Tortoises Make a Comeback in Madagascar. Nature 2020, 587, 548. [CrossRef]

92. Pedrono, M.; Griffiths, O.L.; Clausen, A.; Smith, L.L.; Griffiths, C.J.; Wilme, L.; Burney, D.A. Using a surviving lineage of Madagascar's vanished megafauna for ecological restoration. Biol. Conserv. 2013, 159, 501-506. [CrossRef]

93. Ganzhorn, J.U.; Lowry, P.P.; Schatz, G.E.; Sommer, S. The biodiversity of Madagascar: One of the world's hottest hotspots on its way out. Oryx 2001, 35, 346-348. [CrossRef]

94. Jones, J.P.; Ratsimbazafy, J.; Ratsifandrihamanana, A.N.; Watson, J.E.M.; Andrianandrasana, H.T.; Cabeza, M.; Cinner, J.E.; Goodman, S.M.; Hawkins, F.; Mittermeier, R.A.; et al. Last chance for Madagascar's biodiversity. Nat. Sustain. 2019, 2 , 350-352. [CrossRef]

95. Randriamiharisoa, L.O.; Rakotondravony, D.; Raherilalao, M.J.; Ranirison, A.; Wilme, L.; Ganzhorn, J.U. Effects of transhumance route on the richness and composition of bird communities in Tsimanampesotse National Park. Madag. Conserv. Dev. 2015, 10, 110-115. [CrossRef]

96. Ratovonamana, Y.; Rajeriarison, C.; Roger, E.; Keifer, I.; Ganzhorn, J.U. Impact of livestock grazing on forest structure, plant species composition and biomass in southwestern Madagascar. Scr. Bot. Belg. 2013, 50, 82-92.

97. Randriamalala, J.R.; Radosy, H.O.; Razanaka, S.; Randriambanona, H.; Herve, D. Effects of goat grazing and woody charcoal production on xerophytic thickets of southwestern Madagascar. J. Arid. Environ. 2016, 128, 65-72. [CrossRef]

98. Razanatsoa, E.; Virah-Sawmy, M.; Woodborne, S.; Callanan, C.; Gillson, L. Adaptation of subsistence strategies of the southwestern Malagasy in the face of climate change. Malagasy Nat. 2021, 15, 1-31. 
99. Gardner, C.J.; Davies, Z.G. Rural bushmeat consumption within multiple-use protected areas: Qualitative evidence from southwest Madagascar. Hum. Ecol. 2014, 42, 21-34. [CrossRef]

100. Benstead, J.P.; De Rham, P.H.; Gattolliat, J.L.; Gibon, F.M.; Loiselle, P.V.; Sartori, M.; Sparks, J.S.; Stiassny, M.L.J. Conserving Madagascar's freshwater biodiversity. BioScience 2003, 53, 1101-1111. [CrossRef]

101. Bamford, A.J.; Razafindrajao, F.; Young, R.P.; Hilton, G.M. Profound and pervasive degradation of Madagascar's freshwater wetlands and links with biodiversity. PLOS ONE 2017, 12, e0182673. 